University of Wollongong

Research Online

Faculty of Engineering - Papers (Archive)

Faculty of Engineering and Information

Sciences

2008

\title{
Magnetic structures and phase transitions in PrMn2-xFexGe2
}

Jianli Wang

University of New South Wales, jianli@uow.edu.au

Stewart J. Campbell

University of New South Wales, stewart.campbell@adfa.edu.au

A J Studer

Australian Nuclear Science and Technology Organisation

Maxim Avdeev

Australian Nuclear Science and Technology Organisation

M Hofmann

Technische Universitat Munchen

See next page for additional authors

Follow this and additional works at: https://ro.uow.edu.au/engpapers

Part of the Engineering Commons

https://ro.uow.edu.au/engpapers/4148

\section{Recommended Citation}

Wang, Jianli; Campbell, Stewart J.; Studer, A J; Avdeev, Maxim; Hofmann, M; Hoelzel, M; and Dou, S. X.:

Magnetic structures and phase transitions in PrMn2-xFexGe2 2008, 103911-1-103911-12.

https://ro.uow.edu.au/engpapers/4148

Research Online is the open access institutional repository for the University of Wollongong. For further information contact the UOW Library: research-pubs@uow.edu.au 


\section{Authors}

Jianli Wang, Stewart J. Campbell, A J Studer, Maxim Avdeev, M Hofmann, M Hoelzel, and S. X. Dou 


\title{
Magnetic Structures and Phase Transitions in $\operatorname{PrMn}_{2-\mathrm{x}} \mathrm{Fe}_{\mathrm{x}} \mathrm{Ge}_{2}$
}

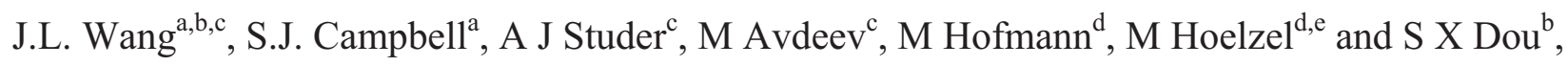

${ }^{a}$ School of Physical, Environmental and Mathematical Sciences, The University of New South

Wales, The Australian Defence Force Academy, Canberra ACT 2600, Australia

${ }^{\mathrm{b}}$ Institute for Superconductivity and Electronic Materials, University of Wollongong,

Wollongong, NSW 2522, Australia

${ }^{c}$ Bragg Institute, ANSTO, Lucas Heights, NSW 2234, Australia

${ }^{\mathrm{d}}$ Technische Universität München, FRM-II, 85747 Garching, Germany

${ }^{\mathrm{e}}$ Technische Universität Darmstadt, Fachbereich Materialwissenschaften, 64287 Darmstadt

\begin{abstract}
The magnetic properties and magnetic structures of $\operatorname{PrMn}_{2-\mathrm{x}} \mathrm{Fe}_{\mathrm{x}} \mathrm{Ge}_{2}$ compounds (space group I4/mmm) have been investigated using magnetic, ${ }^{57} \mathrm{Fe}$ Mössbauer effect $(\mathrm{x}=1.0,1.3,1.6)$ and neutron diffraction measurements $(\mathrm{x}=0.4,0.6,0.8,1.3)$ over the temperature range $3-410 \mathrm{~K}$. This has enabled the existing magnetic phase diagram for $\operatorname{PrMn}_{2-\mathrm{x}} \mathrm{Fe}_{\mathrm{x}} \mathrm{Ge}_{2}$ to be extended from $\mathrm{Fe}$ concentration, $x=0-1$, to the full range $x=0-2$ in terms of concentration and $d_{M n-M n}$, the intralayer distance.
\end{abstract}

Analysis of the Mössbauer spectra $(4.5-300 \mathrm{~K})$ using a model which takes nearest-neighbour environments into account confirms the non-magnetic nature of Fe atoms in these compounds, and leads to hyperfine parameters which deviate around the magnetic transition temperatures derived from the magnetic and neutron investigations, while also enabling the Debye temperatures of $\operatorname{PrMn}_{2-\mathrm{x}} \mathrm{Fe}_{\mathrm{x}} \mathrm{Ge}_{2}(\mathrm{x}=0.4-1.6)$ to be determined. The experimental values for $\mathrm{T}_{\mathrm{C}}{ }^{\text {inter }}$ are found to decrease rapidly with increasing $\mathrm{Fe}$ concentration in the range $\mathrm{x}=0.0-0.6$ compared with 
calculated $\mathrm{T}_{\mathrm{C}}{ }^{\text {inter }}$ values due to pressure (and therefore geometric) effects only. This behaviour demonstrates that electronic effects and replacement of the magnetic Mn atoms with non-magnetic Fe atoms contribute to the overall magnetic behaviour of $\operatorname{PrMn}_{2-\mathrm{x}} \mathrm{Fe}_{\mathrm{x}} \mathrm{Ge}_{2}$ compounds. Compared with intralayer Mn-Mn interactions, the interlayer Mn-Mn interactions play the major role in the anomalous thermal expansion observed at magnetic transition in these layered systems, with the interlayer Mn-Mn interactions governing the significant magnetovolume effects.

Key words: Magnetic phase transition, Magnetic susceptibility, Mössbauer spectroscopy, Intrinsic properties of magnetically ordered materials

PACS: 75.30.Kz, 75.30.Cr, 76.80.+y, 75.30.-m 


\section{Introduction}

As is well known, $\mathrm{RM}_{2} \mathrm{X}_{2}$ compounds ( $\mathrm{R}$ - rare earth, $\mathrm{M}-3 \mathrm{~d}$ or $4 \mathrm{~d}$ metal, $\mathrm{X}-\mathrm{Ge}, \mathrm{Si}$ ) crystallise in a simple body-centred tetragonal $\mathrm{ThCr}_{2} \mathrm{Si}_{2}$ type structure (space group I4/mmm) that can be described as a stacking of atomic layers in the direction of the c-axis with the sequence of RX-M-X-R [1]. The naturally layered crystal structure of these compounds provides unique models for studying the physical phenomena intrinsic for multilayer structures and quasi-two-dimensional magnetic materials [2]. This in turn has contributed to the continued interest in the study of phase transitions in intermetallic compounds of the composition $\mathrm{RM}_{2} \mathrm{X}_{2}$ [e.g. 3-9]. It is well known that in $\mathrm{R}_{1-\mathrm{x}} \mathrm{R}_{\mathrm{x}}^{\prime} \mathrm{Mn}_{2} \mathrm{X}_{2}$ systems [e.g. 3, 4, 9] both the intralayer and the adjacent interlayer Mn-Mn exchange interaction depend primarily on the Mn-Mn intralayer distance $\mathrm{d}^{\mathrm{a}} \mathrm{Mn}-\mathrm{Mn}$ rather than the Mn-Mn interlayer distance $\mathrm{d}_{\mathrm{Mn}-\mathrm{Mn}}^{\mathrm{c}}$.

As reported in a series of studies $[$ e.g. $1-4,9,10]$, the magnetic behaviour depends critically on $\mathrm{d}^{\mathrm{a}}{ }_{\mathrm{Mn}}$ Mn with the interlayer exchange coupling being ferromagnetic and the intralayer coupling antiferromagnetic for $\mathrm{d}^{\mathrm{a}}{ }_{\mathrm{Mn}-\mathrm{Mn}}>\mathrm{d}_{\text {critl }}=2.87 \AA$ leading to the canted ferromagnetic structure Fmc-type as defined by Venturini et al. [3]. $\operatorname{PrMn}_{2} \mathrm{Ge}_{2}$ falls into this category exhibiting the Fmc-type magnetic structure at room temperature with $\mathrm{d}^{\mathrm{a}}{ }_{\mathrm{Mn}-\mathrm{Mn}}=2.92 \AA[11]$. As a second general indicator of magnetic behaviour, with decrease of $\mathrm{d}^{\mathrm{a}}{ }_{\mathrm{Mn}-\mathrm{Mn}}$ in the range $\mathrm{d}_{\text {crit } 2}=2.84 \AA$ (the second critical distance) and $\mathrm{d}_{\text {critl }}=2.87 \AA[9]$, the interlayer coupling changes from ferromagnetic to antiferromagnetic while the intralayer coupling remains antiferromagnetic. Examples of this type of magnetic behaviour include $\mathrm{La}_{0.7} \mathrm{Y}_{0.3} \mathrm{Mn}_{2} \mathrm{Si}_{2}$ and $\mathrm{La}_{0.6} \mathrm{Y}_{0.4} \mathrm{Mn}_{2} \mathrm{Si}_{2}$ with $\mathrm{d}=2.864 \AA$ and $\mathrm{d}=2.854 \AA$ respectively which exhibit AFmc-type magnetic structures at room temperature [e.g. 12-15]. For smaller values of $\mathrm{d}^{\mathrm{a}}{ }_{\mathrm{Mn}-\mathrm{Mn}}$ in the range $\mathrm{d}^{\mathrm{a}}{ }_{\mathrm{Mn}-\mathrm{Mn}}<\mathrm{d}_{\text {crit2 }}=2.84 \AA$, it is found that there is effectively no intralayer in-plane spin component and the interlayer coupling remains antiferromagnetic, leading to the AFil-type magnetic structure [9]. Examples in this third category are $\mathrm{La}_{1-\mathrm{x}} \mathrm{Y}_{\mathrm{x}} \mathrm{Mn}_{2} \mathrm{Ge}_{2}$ with $\mathrm{x}=0.6,0.8$ and 1.0 
for which $\mathrm{d}=2.776 \AA, 2.786 \AA$ and $2.796 \AA$ respectively at room temperature [15], and $\mathrm{YMn}_{2} \mathrm{Ge}_{2}$ with $\mathrm{d}=2.826 \AA$ at room temperature [16].

Given the strong dependence of the interlayer $\mathrm{Mn}-\mathrm{Mn}$ exchange interaction on the intralayer distance $d^{a}{ }_{M n-M n}$, studies of $R_{1-x} R_{x}^{\prime} M_{2} X_{2}$ and $\mathrm{RMn}_{2-\mathrm{x}} \mathrm{T}_{\mathrm{x}} \mathrm{X}_{2}$ systems provide detailed insight as to how the magnetic interactions evolve from one end compound to the other $[$ e.g. 8-10, 17-20]. The $\mathrm{PrMn}_{2-\mathrm{x}} \mathrm{Fe}_{\mathrm{x}} \mathrm{Ge}_{2}$ system is of particular interest as it allows the loss of the moment in the Mn lattice to be investigated as $\mathrm{T}=\mathrm{Mn}$ is replaced by $\mathrm{T}=\mathrm{Fe}$, while exploring the interplay between the ordered $(\mathrm{Mn}, \mathrm{Fe})$ sub-lattice and the Pr sub-lattice. Recent investigations of the crystal structure and magnetic behaviour of $\operatorname{PrMn}_{2-\mathrm{x}} \mathrm{Fe}_{\mathrm{x}} \mathrm{Ge}_{2}(\mathrm{x}=0-1)$ by $\mathrm{x}$-ray powder diffraction and $\mathrm{DC}$ magnetic measurements [19] and neutron diffraction $(\mathrm{x}=0.6,0.8,1.0)[18]$, have resulted in the $\operatorname{PrMn}_{2-}$ ${ }_{x} \mathrm{Fe}_{\mathrm{x}} \mathrm{Ge}_{2}$ magnetic phase diagram for $0 \leq \mathrm{x} \leq 1$. The mixture of interlayer and intralayer interactions in this system leads to relatively complex behaviour with reentrant ferromagnetism - similar to the behaviour of $\mathrm{SmMn}_{2} \mathrm{Ge}_{2}$ [e.g. 20, 21] - being observed. $\mathrm{PrMn}_{1.4} \mathrm{Fe}_{0.6} \mathrm{Ge}_{2}$, for example, exhibits four magnetic transitions: paramagnetism to intralayer in-plane antiferromagnetism at $\mathrm{T}_{\mathrm{N}}^{\text {intra }} \sim 333 \mathrm{~K}$, canted ferromagnetism at $\mathrm{T}_{\mathrm{C}}{ }^{\text {inter }} \sim 168 \mathrm{~K}$ which gives way to canted antiferromagnetism at $\mathrm{T}_{\mathrm{N}}{ }^{\text {inter }} \sim 152 \mathrm{~K}$ before Pr sublattice ordering at $\mathrm{T}_{\mathrm{C}}{ }^{\mathrm{Pr}} \sim 40 \mathrm{~K}$. Our ${ }^{57} \mathrm{Fe}$ Mössbauer effect studies of $\operatorname{PrMn}_{2-\mathrm{x}} \mathrm{Fe}_{\mathrm{x}} \mathrm{Ge}_{2}\left(\mathrm{x}=0.4,0.6\right.$ and 0.8) and neutron diffraction measurements on $\mathrm{PrMn}_{1.2} \mathrm{Fe}_{0.8} \mathrm{Ge}_{2}$ [14] are in good agreement with this partial magnetic phase diagram [18].

Here, in order to investigate the magnetic structures of $\operatorname{PrMn}_{2-\mathrm{x}} \mathrm{Fe}_{\mathrm{x}} \mathrm{Ge}_{2}$ compounds with higher content $\mathrm{Fe}$ we extend our investigation to $\mathrm{PrMn}_{2-\mathrm{x}} \mathrm{Fe}_{\mathrm{x}} \mathrm{Ge}_{2}$ compounds with $\mathrm{x}=1.0$, 1.3 and 1.6 (magnetic and ${ }^{57} \mathrm{Fe}$ Mössbauer measurements) and with $\mathrm{x}=0.4,0.6,0.8$ and 1.3 (neutron diffraction). This has enabled us to extend the current magnetic phase diagram $(0 \leq \mathrm{x} \leq 1)$ to the entire $\operatorname{PrMn}_{2}$ ${ }_{\mathrm{x}} \mathrm{Fe}_{\mathrm{x}} \mathrm{Ge}_{2}$ system $(0 \leq \mathrm{x}<2)$. 


\section{Experimental Details}

The $\mathrm{PrMn}_{2-\mathrm{x}} \mathrm{Fe}_{\mathrm{x}} \mathrm{Ge}_{2}$ compounds were prepared by argon arc melting appropriate amounts of high purity elements on a water-cooled $\mathrm{Cu}$ hearth. An empirical amount of excess Mn (around 2$3 \%$ ) was used to compensate for loss during melting. The sample was remelted five times to ensure good homogeneity and then annealed at $900^{\circ} \mathrm{C}$ for one week in an evacuated quartz tube. The single phase nature of samples was checked by $\mathrm{X}$-ray $(\mathrm{Cu}-\mathrm{K} \alpha$ radiation; $\lambda=1.5418 \AA)$ and the lattice parameters determined at room temperature. The temperature dependence of the magnetisation, M (T), was measured in a Vibrating Sample Magnetometer (VSM) from $5 \mathrm{~K}$ to $300 \mathrm{~K}$ $\left(\mathrm{H}_{\mathrm{appl}}=100 \mathrm{Oe}\right)$ or a superconducting quantum interference device (SQUID) from $5 \mathrm{~K}$ to $350 \mathrm{~K}\left(\mathrm{H}_{\mathrm{appl}}\right.$ $=50 \mathrm{Oe}$ ) after first cooling in zero-field. The field dependence of the magnetization was measured at selected temperatures using the SQUID. ${ }^{57}$ Fe Mössbauer spectra were obtained between $4.5 \mathrm{~K}$ and $300 \mathrm{~K}$ using a standard constant-acceleration spectrometer and a ${ }^{57} \mathbf{C o} \mathbf{R h}$ source. The spectrometer was calibrated at room temperature with an $\alpha$-iron foil. Initial neutron diffraction experiments were carried out on the $\operatorname{PrMn}_{2-\mathrm{x}} \mathrm{Fe}_{\mathrm{x}} \mathrm{Ge}_{2}$ samples with $\mathrm{x}=0.4,0.6,0.8$ and 1.3 using the HRPD $(\lambda=1.8848$ $\AA)$ and MRPD diffractometers $(\lambda=1.6660 \AA)$ at Reactor HIFAR, Lucas Heights over the temperature range $\sim 3-410 \mathrm{~K}$ with detailed neutron diffraction data being collected $(\lambda=1.5487 \AA)$ at $\mathrm{T}=3 \mathrm{~K}$ and $300 \mathrm{~K}$ on the SPODI diffractometer at FRM-II.

\section{Results and Discussion}

\subsection{Crystal Structure}

Fig. 1 shows room temperature X-ray diffraction patterns for $\operatorname{PrMn}_{2-\mathrm{x}} \mathrm{Fe}_{\mathrm{x}} \mathrm{Ge}_{2}$ compounds with $\mathrm{x}=0.4$, 0.8, 1.3 and 1.6 as examples of the compounds investigated. Analysis of the x-ray diffraction patterns showed that all samples are single phase and have the tetragonal body-cantered $\mathrm{ThCr}_{2} \mathrm{Si}_{2^{-}}$ type structure (space group $\mathrm{I} / \mathrm{mmm}$ ) as expected. The $\mathrm{x}$-ray data have been refined using the 
FULLPROF program [22] with the results of the refinements for all compounds listed in Table I. The lattice constants of $\mathrm{PrMn}_{2-\mathrm{x}} \mathrm{Fe}_{\mathrm{x}} \mathrm{Ge}_{2}$ with $\mathrm{x}=0-1.0$ are in good agreement with previously reported values [19]. The bond lengths between different sites have also been calculated and listed in Table I with the BLOKJE program [23] using the structural and positional parameters and the twelve-coordinate metallic radii of $1.82 \AA, 1.26 \AA, 1.35 \AA$ and $1.37 \AA$ for Pr, Fe, Mn and Ge, respectively. From Table I it can be clearly seen that the unit cell volume and the lattice constants as well as the bond lengths $\mathrm{d}_{\mathrm{Mn}-\mathrm{Mn}}, \mathrm{d}_{\mathrm{Pr}-\mathrm{Pr}}$ and $\mathrm{d}_{\mathrm{Mn}-\mathrm{Pr}}$ between $\mathrm{Mn}$ and Pr sites decrease monotonically with increasing $\mathrm{Fe}$ composition due to the smaller atomic size of Fe compared to that of $\mathrm{Mn}$. Moreover, it is found that the in-plane Mn-Mn distances for all compound with $\mathrm{x} \leq 1.6$ are larger than $2.87 \AA$ (the critical intralayer $\mathrm{Mn}-\mathrm{Mn}$ spacing at which the intralayer in-plane Mn-Mn coupling is antiferromagnetic and the interlayer coupling is ferromagnetic for $\mathrm{RMn}_{2} \mathrm{X}_{2}[1,10,18$, $14,24])$.

\subsection{Magnetic Studies}

$\operatorname{Pr} \mathbf{M n}_{1.0} \mathrm{Fe}_{1.0} \mathrm{Ge}_{2}$ : The temperature dependences of magnetisation and inverse magnetization of the $\operatorname{PrMn}_{1.0} \mathrm{Fe}_{1.0} \mathrm{Ge}_{2}$ compound over the temperature range 5-300 $\mathrm{K}$ in an applied field of $\mathrm{H}_{\mathrm{appl}}=50 \mathrm{Oe}$ are shown in Figure 2. Two phase transitions (marked by arrows in Fig. 2) are evident below room temperature. Analogous to the $\operatorname{PrMn}_{1.2} \mathrm{Fe}_{0.8} \mathrm{Ge}_{2}$ compound $[14,18,19]$, these two transitions can be ascribed to an initial transition from paramagnetism to an intraplanar AF state at $\mathrm{T}_{\mathrm{N}}{ }^{\text {intra }}$ (higher temperature transition) with a subsequent transition to an interlayer $\mathrm{AF}$ state at $\mathrm{T}_{\mathrm{N}}{ }^{\text {inter }}$ (lower temperature transition) as confirmed by neutron diffraction [18] and our Mössbauer spectroscopy experiments outlined below.

$\operatorname{PrMn}_{\text {0.7 }} \mathrm{Fe}_{1.3} \mathrm{Ge}_{2}$ : The temperature dependences of magnetization and the inverse magnetization for $\operatorname{PrMn}_{0.7} \mathrm{Fe}_{1.3} \mathrm{Ge}_{2}$ are shown in Fig. 3(a). As in the case of $\operatorname{PrMn}_{1.0} \mathrm{Fe}_{1.0} \mathrm{Ge}_{2}$, two phase transitions are 
detected below room temperature (the first transition around $103 \mathrm{~K}$ is more evident in the $\mathrm{dM} / \mathrm{dT}$ curve shown as an insert to Fig. 3(a)). With decrease in temperature the magnetization of $\operatorname{PrMn}_{0.7} \mathrm{Fe}_{1.3} \mathrm{Ge}_{2}$ is found to increase monotonically below the second transition temperature (around $56 \mathrm{~K})$ which on first impression reflects a ferromagnetic-like character. In order to clarify which type of magnetic ordering the $(\mathrm{Mn}, \mathrm{Fe})$ sublattice of the $\operatorname{PrMn}_{0.7} \mathrm{Fe}_{1.3} \mathrm{Ge}_{2}$ compound displays below $56 \mathrm{~K}$ - ferromagnetic or antiferromagnetic - we have measured the $\mathrm{M}-\mathrm{H}$ curves at various temperatures (Fig. 3(b)). It can be seen that below $\mathrm{T}_{\mathrm{N}}^{\text {intra }}=56 \mathrm{~K}$ the $\mathrm{M}-\mathrm{H}$ curves reflect a typical antiferromagnetic behaviour. This conclusion is also reflected by the behaviour of Arrott-plots of $\mathrm{M}^{2}$, the magnetisation squared as a function of $\mathrm{H} / \mathrm{M}$ as shown in Fig. 3(c) where the intercept on the $\mathrm{M}^{2}$ axis extrapolated from the high fields is negative for all temperatures investigated, thus excluding the possibility of ferromagnetic ordering.

$\operatorname{PrMn}_{\text {0.4 }} \mathrm{Fe}_{1.6} \mathrm{Ge}_{2}$ : As shown by Fig. 4, the $\operatorname{PrMn}_{0.4} \mathrm{Fe}_{1.6} \mathrm{Ge}_{2}$ compound exhibits similar behaviour to that obtained for the $\operatorname{PrMn}_{1.0} \mathrm{Fe}_{1.0} \mathrm{Ge}_{2}$ and $\operatorname{PrMn}_{0.7} \mathrm{Fe}_{1.3} \mathrm{Ge}_{2}$ samples of Figs. 2 and 3. In the case of $\operatorname{PrMn}_{0.4} \mathrm{Fe}_{1.6} \mathrm{Ge}_{2}$, the two transition temperatures have been derived to be $\mathrm{T}_{\mathrm{N}}^{\text {intra }}=66 \mathrm{~K}$ and $\mathrm{T}_{\mathrm{N}}^{\text {inter }}=38$ K. Combined with earlier data for $\operatorname{PrMn}_{1.2} \mathrm{Fe}_{0.8} \mathrm{Ge}_{2}[14,18]$, it can be seen that both $\mathrm{T}_{\mathrm{N}}{ }^{\text {intra }}$ and $\mathrm{T}_{\mathrm{N}}{ }^{\text {inter }}$ decrease monotonically with increasing $\mathrm{Mn}$ content. Moreover, similar to the case of $\operatorname{PrMn}_{1.2} \mathrm{Fe}_{0.8} \mathrm{Ge}_{2}[14,18,19], \operatorname{PrMn}_{2-\mathrm{x}} \mathrm{Fe}_{\mathrm{x}} \mathrm{Ge}_{2}$ compounds with Fe contents in the range $\mathrm{x}=1.0-1.6$ are paramagnetic at room temperature but with a larger in-plane Mn-Mn spacing $(>2.87 \AA$, see Table I); this behaviour is consistent with our earlier conclusion that the magnetic coupling is not determined solely by geometric criteria [14].

\subsection{Mössbauer Spectroscopy}

Figures 5, 6 and 7 show variable temperature ${ }^{57} \mathrm{Fe}$ Mössbauer spectra $(4.5-300 \mathrm{~K})$ for the $\operatorname{PrMn}_{1.0} \mathrm{Fe}_{1.0} \mathrm{Ge}_{2}, \operatorname{PrMn}_{0.7} \mathrm{Fe}_{1.3} \mathrm{Ge}_{2}$ and $\mathrm{PrMn}_{0.4} \mathrm{Fe}_{1.6} \mathrm{Ge}_{2}$ samples, respectively. In agreement with the 
magnetic results outlined above, it is evident from the room temperature spectra that all of the $\operatorname{PrMn}_{2-\mathrm{x}} \mathrm{Fe}_{\mathrm{x}} \mathrm{Ge}_{2}$ compounds with $\mathrm{x}=1.0,1.3$ and 1.6 are paramagnetic at room temperature.

Spectral Fits: Analyses of the Mössbauer spectra of $\operatorname{PrMn}_{2-\mathrm{x}} \mathrm{Fe}_{\mathrm{x}} \mathrm{Ge}_{2}$ systems have been carried out using the same model as described previously [14] which takes into account the nearest-neighbour $(\mathrm{nn})$ environments. The numbers of nearest-neighbour $2 \mathrm{a}(\mathrm{R}), 4 \mathrm{~d}(\mathrm{~T})$ and $4 \mathrm{e}(\mathrm{Ge})$ sites to the $4 \mathrm{~d}$ sites on which the Fe atoms reside are 4, 4 and 4 respectively. Assuming that the Fe atoms occupy the $4 \mathrm{~d}$ site randomly, the iron atoms would have binomial distributions of nearest-neighbour $\mathrm{Mn}$ environments. In the case of $\operatorname{PrMn}_{1.0} \mathrm{Fe}_{1.0} \mathrm{Ge}_{2}$ for example, a magnetically split spectrum can be represented by five sextets with fractional areas of $0.063,0.250,0.375,0.250$ and 0.063 . These sextets represent $\mathrm{Fe}$ atoms with zero, one, two, three and four nearest-neighbour $\mathrm{Fe}$ atoms, respectively. The equivalent fractional areas for $\operatorname{PrMn}_{0.7} \mathrm{Fe}_{1.3} \mathrm{Ge}_{2}$ and $\mathrm{PrMn}_{0.4} \mathrm{Fe}_{1.6} \mathrm{Ge}_{2}$ are $(0.015$, $0.111,0.311,0.384$ and 0.179$)$ and $(0.002,0.026,0.154,0.410$ and 0.410$)$ respectively. Given that the contribution from the sub-sextet corresponding to zero nearest-neighbour Fe atoms in the $\operatorname{PrMn}_{0.4} \mathrm{Fe}_{1.6} \mathrm{Ge}_{2}$ is only $0.2 \%$, it has been omitted in the fitting process.

The solid lines in Figures 5, 6 and 7 represents the fits obtained to the magnetically split $\operatorname{PrMn}_{2-}$ ${ }_{x} \mathrm{Fe}_{\mathrm{x}} \mathrm{Ge}_{2}$ spectra on the basis of this binomial distribution model. Emphasis was placed on fitting the 4.5 K spectrum for each compound, with the final fit parameters then being used as the basis for the initial parameters in analysis of the higher temperature spectra. The fits were obtained with the five sub-spectra (four for $\mathrm{x}=1.6$ ) constrained to the fractional binomial areas as described above and using the same line-width for each sub-spectral component. The magnetic hyperfine field $\mathrm{B}_{\mathrm{hf}}$ for each sextet component was allowed to vary although, to reduce the number of parameters, and because of the similarity in their values, the isomer shift $\delta$ and quadrupole shift $\varepsilon$ were varied during the fits but assumed to be the same for each sub-spectral component. Good quality fits were 
obtained to the spectra and the nearest-neighbour environment for each sub-spectrum can be assigned by taking into account the influence of the iron atoms on the magnetic hyperfine field and related magnetic moment. As reported elsewhere [e.g. 14, 25, 26], Fe atoms do not carry a magnetic moment in $\mathrm{RFe}_{2} \mathrm{X}_{2}$ or in ${ }^{57} \mathrm{Fe}$ doped $\mathrm{RT}_{2} \mathrm{X}_{2}$ compounds. The present findings are also consistent with the behaviour of $\mathrm{Fe}$ as a nonmagnetic probe in $\mathrm{PrMn}_{2-\mathrm{x}} \mathrm{Fe}_{\mathrm{x}} \mathrm{Ge}_{2}$. In the case of $\operatorname{PrMn}_{1.0} \mathrm{Fe}_{1.0} \mathrm{Ge}_{2}$ for example (Figure 5), the subspectrum with the largest $\mathrm{B}_{\mathrm{hf}}$ is attributed to $\mathrm{Fe}$ atoms having the largest $\mathrm{Mn}$ coordination (i.e. zero Fe nn) and the smallest $\mathrm{B}_{\mathrm{hf}}$ is attributed to Fe atoms having the largest $\mathrm{Fe}$ coordination (five $\mathrm{Fe} \mathrm{nn}$ ) in these compounds. Examples of the subspectral components for the three ${ }^{57} \mathrm{Fe}$-doped $\operatorname{PrMn}_{2-\mathrm{x}} \mathrm{Fe}_{\mathrm{x}} \mathrm{Ge}_{2}$ compounds are shown in the $4.5 \mathrm{~K}$ spectra of Figures 5, 6, and 7.

Hyperfine Parameters: Figures 8, 9 and 10 show the temperature dependences of the Mössbauer hyperfine parameters for $\operatorname{PrMn}_{2-\mathrm{x}} \mathrm{Fe}_{\mathrm{x}} \mathrm{Ge}_{2}$ compounds with $\mathrm{x}=1.0,1.3$ and 1.6 respectively. Similar to the case of $\operatorname{PrMn}_{1.2} \mathrm{Fe}_{0.8} \mathrm{Ge}_{2}$, the absence of magnetic hyperfine splitting above $\mathrm{T}_{\mathrm{N}}{ }^{\text {intra }}$ for each of the present $\operatorname{PrMn}_{2-\mathrm{x}} \mathrm{Fe}_{\mathrm{x}} \mathrm{Ge}_{2}$ compounds ( $\mathrm{x}=1.0,1.3$ and 1.6; see also Figs 5, 6 and 7), confirms that $\mathrm{T}_{\mathrm{N}}{ }^{\text {intra }}$ corresponds to a transition from antiferromagnetism to paramagnetism in these samples. Likewise, persistence of the magnetic hyperfine splitting below $\mathrm{T}_{\mathrm{N}}{ }^{\text {inter }}$ corresponds to the transition from intralayer antiferromagnetism (AFl) to interlayer antiferromagnetism (AFmc) at lower temperatures [14] as confirmed by neutron diffraction work outlined below. It has been accepted [26] that, if the observed hyperfine field is the transferred hyperfine field, it should be due only to the neighbour magnetic moments (here $\mathrm{Mn}$ is the only magnetic atom). In Fig. 8(a) we also show the Mn magnetic moment for $\operatorname{PrMn}_{1.0} \mathrm{Fe}_{1.0} \mathrm{Ge}_{2}$ as deduced from neutron diffraction experiments [18] for comparison with the average hyperfine field values $\left\langle\mathrm{B}_{\mathrm{hf}}>\right.$. It is clear that while the hyperfine field and magnetic moment values show similar temperature dependent trends, the reduced value of $<\mathrm{B}_{\mathrm{hf}}>$ relative to $\mathrm{M}_{\mathrm{tot}}(\mathrm{Mn})$ confirms, as discussed above, that the Fe atom acts as a nonmagnetic 
probe in these $\mathrm{RT}_{2} \mathrm{X}_{2}$ compounds [e.g. 14, 25, 26] and that Fe does not carry a magnetic moment in the $\operatorname{PrMn}_{2-\mathrm{x}} \mathrm{Fe}_{\mathrm{x}} \mathrm{Ge}_{2}$ system.

It is also evident from Figures 8,9 and 10 that the variations of the $\varepsilon$ values correlate in general with the transition temperatures as determined from the magnetic measurements of Figs 2, 3 and 4. For $\mathrm{T}>\mathrm{T}_{\mathrm{N}}{ }^{\text {intra }}$, the quadrupole shift $\varepsilon$ is derived from the quadrupole splitting $\Delta(\varepsilon=\Delta / 2$ here). The effective quadrupole interaction is given by $E Q=1 / 4 \mathrm{e}^{2} \mathrm{qQ}\left(3 \cos ^{2} \theta-1\right)$ where $\mathrm{q}$ is the local axially symmetric electric field gradient and $\theta$ is the angle between the direction of the magnetic moment (or magnetic hyperfine field) and the principal axis of the electric-field gradient (the c-axis in the present systems). Since q changes slowly with temperature, any significant change in EQ is likely to be associated with a sudden change in $\theta$, namely, a change in the orientation of the Mn moments as has been established in the case of $\mathrm{LaMn}_{2} \mathrm{Si}_{2}[3,10]$ and $\mathrm{YbMn}_{2} \mathrm{Ge}_{2}$ [27]. This is also consistent with the present behaviour for $\operatorname{PrMn}_{2-\mathrm{x}} \mathrm{Fe}_{\mathrm{x}} \mathrm{Ge}_{2}$ as, below $\mathrm{T}_{\mathrm{N}}{ }^{\text {inter }}$ (for $\mathrm{x} \geq 0.8$ ) or $\mathrm{T}_{\mathrm{C}}{ }^{\text {inter }}$ (for $\mathrm{x}<0.8$ [14]), $\operatorname{PrMn}_{2-\mathrm{x}} \mathrm{Fe}_{\mathrm{x}} \mathrm{Ge}_{2}$ compounds exhibit a canted magnetic structure (AFmc-type for $\mathrm{x} \geq 0.8$; Fmc for $\mathrm{x} \leq 0.6)[14,18]$ which means that below $\mathrm{T}_{\mathrm{N}}{ }^{\text {inter }}$ or $\mathrm{T}_{\mathrm{C}}{ }^{\text {inter }}$ the value of $\theta$ deviates from $90^{\circ}$. Moreover, the anisotropic temperature dependences of the lattice parameters a and c detected in $\operatorname{PrMn}_{2-\mathrm{x}} \mathrm{Fe}_{\mathrm{x}} \mathrm{Ge}_{2}$ through these magnetic transitions (see below for $\mathrm{x}=0.4$ and reference $[14,18]$ for $\mathrm{x}$ $=0.6,0.8,1.0)$, may also influence the variation of QS by modifying the lattice contribution to the the electric field gradient (EFG) [10].

Values of the Debye temperatures, $\theta_{D}$, for our series of ${ }^{57} \mathrm{Fe}$ doped $\mathrm{PrMn}_{2-\mathrm{x}} \mathrm{Fe}_{\mathrm{x}} \mathrm{Ge}_{2}$ compounds have been determined from the temperature dependence of the isomer shift IS(T) [28]:

$$
I S(T)=I S_{0}(T)+I S_{S O D S}(T)
$$


$I S_{0}(T)$ represents the $T$-dependence of the charge density at the probe nucleus (which is generally weakly temperature dependent) with $I S_{S O D S}$, the second-order Doppler shift, described in terms of the Debye model for the phonon spectrum by:

$$
I S_{\text {SODS }}(T)=-\frac{3 k T}{2 m c}\left[\frac{3 \theta_{D}}{8 T}+3\left(\frac{T}{\theta_{D}}\right)^{3} \int^{\tau} \frac{x^{3}}{e^{x}-1} d x\right]
$$

$m$ is the mass of the ${ }^{57} \mathrm{Fe}$ nucleus, $k$ Boltzmann's constant, $c$ the velocity of light, and $\tau=\theta_{\mathrm{D}} / T$ the reduced temperature $[29,30]$. Figs $8(\mathrm{c}), 9(\mathrm{c})$ and $10(\mathrm{c})$ show the mean isomer shift values for $\operatorname{PrMn}_{2-\mathrm{x}} \mathrm{Fe}_{\mathrm{x}} \mathrm{Ge}_{2}(\mathrm{x}=1.0,1.3$ and 1.6) along with fits of the IS(T) data to equation (2). These best fits lead to values of $\theta_{D}=380 \pm 20 \mathrm{~K}, 400 \pm 20 \mathrm{~K}$ and $420 \pm 20 \mathrm{~K}$ for $\operatorname{PrMn}_{1.0} \mathrm{Fe}_{1.0} \mathrm{Ge}_{2}, \operatorname{PrMn}_{0.7} \mathrm{Fe}_{1.3} \mathrm{Ge}_{2}$ and $\mathrm{PrMn}_{0.4} \mathrm{Fe}_{1.6} \mathrm{Ge}_{2}$ respectively. The compositional dependence of the calculated $\Theta_{D}$ values for our set of $\operatorname{PrMn}_{2-\mathrm{x}} \mathrm{Fe}_{\mathrm{x}} \mathrm{Ge}_{2}$ compounds $(0.4 \leq \mathrm{x} \leq 1.6$; present data and [14]) are shown in Fig. 11(d). The $\Theta_{D}$ values show a systematic increase with increasing Fe content from $\theta_{D}=350 \pm 20 \mathrm{~K}$ for $\operatorname{PrMn}_{1.6} \mathrm{Fe}_{0.4} \mathrm{Ge}_{2}$ to $\theta_{D}=420 \pm 20 \mathrm{~K}$ for $\operatorname{PrMn}_{0.4} \mathrm{Fe}_{1.6} \mathrm{Ge}_{2}$. This increase in Debye temperature for $\mathrm{PrMn}_{2-\mathrm{x}} \mathrm{Fe}_{\mathrm{x}} \mathrm{Ge}_{2}$ with increasing Fe content is consistent with the difference in Debye temperatures for $\mathrm{Mn}: \Theta_{D}^{\mathrm{Mn}} \sim 400 \mathrm{~K}$ and $\mathrm{Fe}: \Theta_{D}^{\mathrm{Fe}} \sim 460 \mathrm{~K}[31]$.

The compositional dependences of the Mössbauer hyperfine parameters for $\operatorname{PrMn}_{2-\mathrm{x}} \mathrm{Fe}_{\mathrm{x}} \mathrm{Ge}_{2}$ at $4.5 \mathrm{~K}$ are shown in Figs. 11(a), 11(b), 11(c). It is noticed that the trends of the hyperfine parameters deviate slightly around $\mathrm{x} \sim 0.7-0.9$. Based on the magnetic phase diagram for $\operatorname{PrMn}_{2-\mathrm{x}} \mathrm{Fe}_{\mathrm{x}} \mathrm{Ge}_{2}$ for $0<\mathrm{X}<1$ ([18]; reproduced as part of Fig 12), this concentration region at $4.5 \mathrm{~K}$ appears to correspond to the critical concentration $\mathrm{x}_{\mathrm{c}} \sim 0.7-0.9$ for transformation of the $\mathrm{Fmc}+\mathrm{F}(\mathrm{Pr})$ magnetic structure to the AFmc magnetic structure. The boundary for this transformation has therefore been extrapolated by us (dot-dash line in Fig 12) from the earlier diagram of Dincer et al. [18]. Similar behaviour in which hyperfine parameters exhibit a pronounced change at critical composition between two magnetic structures has been observed in the $\mathrm{La}_{1-\mathrm{x}} \mathrm{Y}_{\mathrm{x}} \mathrm{Mn}_{2} \mathrm{Si}_{2}$ system [10]. It should also be noted 
that the combined ferromagnetic regions of the Mn- and Pr-sublattices in the Mn-rich region of the phase diagram of Fig 12, exhibit both $\mathrm{Fmi}+\mathrm{F}(\mathrm{Pr})$ and $\mathrm{Fmc}+\mathrm{F}(\mathrm{Pr})$ regions, the Fmi phase having been delineated in the earlier work of Welter et al. [11]. It should also be noted that the boundary separating the Fmi and Fmc phases in this region of combined ferromagnetic Mn- and Pr-sublattices has not yet been delineated. The present diagram shows an extrapolation (dotted line) of the Fmi/Fmc boundary from the higher temperature region reported previously $[11,18]$.

\subsection{Neutron Studies}

\subsection{1 $\operatorname{PrMn}_{1.6} \mathrm{Fe}_{0.4} \mathrm{Ge}_{2}$}

Representative variable temperature neutron powder diffraction patterns for $\operatorname{PrMn}_{1.6} \mathrm{Fe}_{0.4} \mathrm{Ge}_{2}$ are shown in Figs 13 (a)-(f). The full lines and markers represent Rietveld refinements carried out using FULLPROF [22] which allows simultaneous refinement of the structural and magnetic parameters. The powder diffraction data at $\mathrm{T}=410 \mathrm{~K}$ for $\operatorname{PrMn}_{1.6} \mathrm{Fe}_{0.4} \mathrm{Ge}_{2}$ (i.e. above $\mathrm{T}_{\mathrm{N}}{ }^{\text {intra }} \sim 370 \mathrm{~K}$ $[14,19]$ where $\operatorname{PrMn}_{1.6} \mathrm{Fe}_{0.4} \mathrm{Ge}_{2}$ is paramagnetic) has been used to confirm the crystal structure and derive nuclear scattering information.

As noted in earlier investigations [e.g. 5, 9, 18, 20], the distinctive magnetic structures for this class of $\mathrm{RMn}_{2} \mathrm{X}_{2}$ compounds can be readily distinguished from the thermal evolution of certain reflections such as (101), (111) and (112). In the case of $\operatorname{PrMn}_{1.6} \mathrm{Fe}_{0.4} \mathrm{Ge}_{2}$ for example (Fig 13), in agreement with the neutron diffraction results of Dincer et al. [18], the increase in intensity of the (101) and (103) peaks at $300 \mathrm{~K}$ compared with $410 \mathrm{~K}$ (see Fig. 13 (e) for the (101) peak) can be ascribed to a magnetic contribution from the intralayer antiferromagnet AFl (ordering of $\mathrm{Mn}$ moments within the (001) Mn planes). Likewise the enhanced intensity of the (112) peak at $180 \mathrm{~K}$ (see Fig. 13 (f)) and essentially unchanged intensities for the (101) and (103) confirms that $\mathrm{PrMn}_{1.6} \mathrm{Fe}_{0.4} \mathrm{Ge}_{2}$ is ferromagnetic below $\mathrm{T}_{\mathrm{C}}{ }^{\text {inter }} \sim 230 \mathrm{~K}$ with the Fmc magnetic structure as 
established by Dincer et al. [18]. As shown in Fig. 13 (f), further decrease in temperature to below $\mathrm{T}_{\mathrm{C}}{ }^{\mathrm{Pr}} \sim 30 \mathrm{~K}$ reveals an increase in intensity of the (112) peak at $20 \mathrm{~K}$ due to the additional ferromagnetic ordering of the Pr sublattice as also detected by magnetic measurements [14, 18]. The structural and magnetic parameters for $\mathrm{PrMn}_{1.6} \mathrm{Fe}_{0.4} \mathrm{Ge}_{2}$ at selected temperatures are summarised in Table II.

Figures 14 (a), (b), (c) and (d) show the variation of the unit cell parameters and magnetic moments of $\operatorname{PrMn}_{1.6} \mathrm{Fe}_{0.4} \mathrm{Ge}_{2}$ with temperature over the range $20-410 \mathrm{~K}$, respectively. In order to show more readily the correlation between magnetic structure and lattice parameters, we reproduce the M-T curve of $\mathrm{PrMn}_{1.6} \mathrm{Fe}_{0.4} \mathrm{Ge}_{2}$ in Fig 14(e) [14]. It is clear that the magnetic transition temperatures $\mathrm{T}_{\mathrm{C}}{ }^{\text {inter }}$ and $\mathrm{T}_{\mathrm{C}}{ }^{\mathrm{Pr}}$ for $\mathrm{PrMn}_{1.6} \mathrm{Fe}_{0.4} \mathrm{Ge}_{2}$ are marked by changes in the lattice constants a, $\mathrm{c}$, the ratio c/a and the unit cell volume $\mathrm{V}$ while the onset of intraplanar $\mathrm{AF}$ coupling at $\mathrm{T}_{\mathrm{N}}{ }^{\text {intra }} \sim 370 \mathrm{~K}$ is characterised by a relatively smooth decrease in both the a and c lattice parameters. Combined with the neutron results for $\operatorname{PrMn}_{2-\mathrm{x}} \mathrm{Fe}_{\mathrm{x}} \mathrm{Ge}_{2}$ compounds with $\mathrm{x}=0.6,0.8$ and $1.0[14,18]$ where an anisotropic thermal expansion has been detected below $\mathrm{T}_{\mathrm{N}}{ }^{\text {inter }}$, it can be concluded that the interlayer interactions play a critical role in governing the anomalous thermal expansion observed in these systems. Fig. 14 also reveals a clear anomaly in the a, c and $\mathrm{V}$ parameters at $\mathrm{T}_{\mathrm{C}}{ }^{\mathrm{Pr}}$; this reflects additional contributions to the thermal expansion from the Mn-Pr and Pr-Pr magnetic exchange interactions as a result of the Pr magnetic ordering in $\operatorname{PrMn}_{1.6} \mathrm{Fe}_{0.4} \mathrm{Ge}_{2}$. Combined with the strong interlayer Mn-Mn interactions, the Mn-Pr and Pr-Pr couplings may play a role in determining the magnetic and magnetocaloric properties of these layered structure compounds. As examples, Kumar et al. [32] have recently reported a significant magnetocaloric effect (MCE) in $\mathrm{SmMn}_{2} \mathrm{Ge}_{2}$, both at ambient and applied pressures, due to the strong Sm-Mn coupling while Zeng et al. [33] have recently reported acceptable values for $\operatorname{PrMn}_{1.6} \mathrm{Fe}_{0.4} \mathrm{Ge}_{2}$ compared with those of existing MCE systems. 


\subsection{2 $\operatorname{PrMn}_{1.2} \mathrm{Fe}_{0.8} \mathrm{Ge}_{2}$ and $\operatorname{PrMn}_{0.7} \mathrm{Fe}_{1.3} \mathrm{Ge}_{2}$}

Neutron powder diffraction patterns at various temperatures for $\operatorname{PrMn}_{1.2} \mathrm{Fe}_{0.8} \mathrm{Ge}_{2}$ and $\mathrm{PrMn}_{0.7} \mathrm{Fe}_{1.3} \mathrm{Ge}_{2}$ are shown in Figs 15 and 16, respectively. Compared with $\mathrm{PrMn}_{1.6} \mathrm{Fe}_{0.4} \mathrm{Ge}_{2}(\mathrm{Fig}$. 14), no coherent magnetic scattering is observed in $\operatorname{PrMn}_{1.2} \mathrm{Fe}_{0.8} \mathrm{Ge}_{2}$ and $\operatorname{PrMn}_{0.7} \mathrm{Fe}_{1.3} \mathrm{Ge}_{2}$ at room temperature consistent with the magnetisation and our earlier ${ }^{57} \mathrm{Fe}$ Mössbauer results [14]. Below $\mathrm{T}_{\mathrm{N}}{ }^{\text {intra }}$, in good agreement with the recent findings of Dincer et al. [18] and our ${ }^{57} \mathrm{Fe}$ Mössbauer results [14], $\operatorname{PrMn}_{1.2} \mathrm{Fe}_{0.8} \mathrm{Ge}_{2}$ and $\mathrm{PrMn}_{0.7} \mathrm{Fe}_{1.3} \mathrm{Ge}_{2}$ exhibit AFl-type antiferromagnetic ordering within the (001) Mn layers. With further decrease in temperature the mixed commensurate magnetic structure $A F m c$ is formed below $\mathrm{T}_{\mathrm{N}}^{\text {inter }}=154 \mathrm{~K}$ [14] and $56 \mathrm{~K}$ for $\operatorname{PrMn}_{1.2} \mathrm{Fe}_{0.8} \mathrm{Ge}_{2}$ and $\operatorname{PrMn}_{0.7} \mathrm{Fe}_{1.3} \mathrm{Ge}_{2}$, respectively. As outlined elsewhere, reflections of the type $h+k+l=2 n+1$ are based on a collinear antiferromagnetic structure between the adjacent Mn planes [e.g. 5, 18]. The occurrence of (111), (113) and (201) peaks in $\operatorname{PrMn}_{1.2} \mathrm{Fe}_{0.8} \mathrm{Ge}_{2}$ (Fig. 15) and $\mathrm{PrMn}_{0.7} \mathrm{Fe}_{1.3} \mathrm{Ge}_{2}$ (Fig. 16) at $3 \mathrm{~K}$ indicates antiferromagnetic interactions between the adjacent $\mathrm{Mn}$ planes and AFmc type ordering below the transition temperatures $\mathrm{T}_{\mathrm{N}}{ }^{\text {inter }}=154 \mathrm{~K} \mathrm{[14]}$ and $\mathrm{T}_{\mathrm{N}}{ }^{\text {inter }}=56 \mathrm{~K}$ respectively. The structural and magnetic parameters for $\mathrm{PrMn}_{0.7} \mathrm{Fe}_{1.3} \mathrm{Ge}_{2}$ at $3 \mathrm{~K}$ and $300 \mathrm{~K}$ are summarised in Table II.

\subsubsection{PrMn $2-\mathrm{x} \mathrm{Fe}_{\mathrm{x}} \mathrm{Ge}_{2}$ - Magnetic Phase Diagram}

As shown in Figure 12, the present findings combined with our earlier results [14] enables us to extend the magnetic phase diagram derived for $\operatorname{PrMn}_{2-\mathrm{x}} \mathrm{Fe}_{\mathrm{x}} \mathrm{Ge}_{2}$ for $\mathrm{x}=0-1$ [18], to the magnetic phase diagram over the Fe concentration $x=0-2$. While the Mn sublattice maintains ferromagnetic or antiferromagnetic order across the entire Mn compositional range, the Pr sublattice only exhibits magnetic order for the Mn-rich corner $(0<\mathrm{x}<\sim 0.8)$ and for $\mathrm{PrFe}_{2} \mathrm{Ge}_{2}$ [25]. The $\operatorname{Pr}$ sublattice orders ferromagnetically for Mn-rich compounds $\left(\mathrm{T}_{\mathrm{C}}{ }^{\mathrm{Pr}}\right.$ decreases monotonically from $\mathrm{T}_{\mathrm{C}}{ }^{\mathrm{Pr}}=100 \mathrm{~K}$ 
for $\operatorname{PrMn}_{2} \mathrm{Ge}_{2}[18]$ to $\mathrm{T}_{\mathrm{C}}^{\mathrm{Pr}}=0 \mathrm{~K}$ around $\mathrm{x} \sim 0.8$ ) while the Pr sublattice orders antiferromagnetically in $\mathrm{PrFe}_{2} \mathrm{Ge}_{2}$ below $\mathrm{T}_{\mathrm{N}}{ }^{\mathrm{Pr}}=14 \mathrm{~K}$ [25]. As discussed below, neutron diffraction measurements confirm that the Pr sublattice does not carry a magnetic moment for $\operatorname{PrMn}_{2-\mathrm{x}} \mathrm{Fe}_{\mathrm{x}} \mathrm{Ge}_{2}$ samples with $\mathrm{x}=0.8-1.6$.

Following Dincer et al. [18], Fig. 17 shows the magnetic phase diagram for $\operatorname{PrMn}_{2-\mathrm{x}} \mathrm{Fe}_{\mathrm{x}} \mathrm{Ge}_{2}$ in terms of the Mn-Mn spacing $\mathrm{d}^{\mathrm{a}}{ }_{\mathrm{Mn}-\mathrm{Mn}}$ and the related $a$-lattice parameter $\left(\mathrm{d}^{\mathrm{a}}{ }_{\mathrm{Mn}-\mathrm{Mn}}=\mathrm{a} / \sqrt{ } 2\right)$. It can be seen that even though the $\mathrm{d}^{\mathrm{a}} \mathrm{Mn}-\mathrm{Mn}$ intraplanar spacings for all $\mathrm{PrMn}_{2-\mathrm{x}} \mathrm{Fe}_{\mathrm{x}} \mathrm{Ge}_{2}$ compounds at room temperature are larger than the first critical value $\mathrm{d}_{\text {critl }}=2.87 \AA$, only $\operatorname{PrMn}_{2} \mathrm{Ge}_{2}$ obeys the rule claimed for $\mathrm{RMn}_{2} \mathrm{X}_{2}$ systems with $\mathrm{d}_{\mathrm{Mn}-\mathrm{Mn}}^{\mathrm{a}}>\sim 2.87 \AA$ in which the intralayer in-plane coupling is antiferromagnetic and the interlayer coupling is ferromagnetic (see section 1). Fig. 17 reveals clearly that for $\operatorname{PrMn}_{2-\mathrm{x}} \mathrm{Fe}_{\mathrm{x}} \mathrm{Ge}_{2}$ with $\mathrm{x}=0.2,0.4$ and 0.6 , the ferromagnetic interlayer coupling is shifted to lower temperatures with increasing Fe concentration while for $\operatorname{PrMn}_{2-\mathrm{x}} \mathrm{Fe}_{\mathrm{x}} \mathrm{Ge}_{2}$ with $\mathrm{x} \geq$ 0.8 the ferromagnetic ordering of the interlayer coupling remains unformed down to $5 \mathrm{~K}$. On the other hand the AFme magnetic structure in which both the intralayer in-plane and the interlayer couplings are antiferromagnetic has been detected for $\operatorname{PrMn}_{2-\mathrm{x}} \mathrm{Fe}_{\mathrm{x}} \mathrm{Ge}_{2}$ compounds with $\mathrm{x}>\sim 0.6$ (Figs 12, 17), thus again demonstrating that for the $\operatorname{PrMn}_{2-\mathrm{x}} \mathrm{Fe}_{\mathrm{x}} \mathrm{Ge}_{2}$ system, electronic effects have altered the critical geometric values associated with the magnetic phase transitions.

That electronic effects - in which substitution of $\mathrm{Mn}\left(3 d^{5} 4 s^{2}\right)$ for Fe $\left(3 d^{6} 4 s^{2}\right)$ leads to modification of the electron environment - also play a role, is supported by recent density functional theory calculations for $\mathrm{RMn}_{2} \mathrm{Ge}_{2}(\mathrm{R}=\mathrm{Y}, \mathrm{Ca})$ compounds [34]. These latter studies report that, to a larger extent, the magnetic moments are determined by the interatomic Mn-Mn distances and the interstitial electron density mainly influences the magnetic structures. 
A further factor in the overall behaviour of the $\operatorname{PrMn}_{2-\mathrm{x}} \mathrm{Fe}_{\mathrm{x}} \mathrm{Ge}_{2}$ system is the influence of the non magnetic $\mathrm{Fe}$ atoms on the magnetic ordering temperatures. An estimation of the combined influence of electronic and dopant non-magnetic $\mathrm{Fe}$ atoms on the $\mathrm{T}_{\mathrm{C}}{ }^{\text {inter }}$ transition temperatures in $\operatorname{PrMn}_{2-\mathrm{x}} \mathrm{Fe}_{\mathrm{x}} \mathrm{Ge}_{2}$ can be determined using Fig 18. Fig 18(a) shows the measured changes in unit cell volume with pressure (normalised to unity at $\mathrm{p}=0$ ) for the $\mathrm{RT}_{2} \mathrm{X}_{2}$ compounds $\mathrm{CeNi}_{2} \mathrm{Ge}_{2}[35]$ and $\mathrm{LaMn}_{2} \mathrm{Si}_{2}$ [36] along with the fits to the experimental data derived by the Murnaghan equation $\mathrm{p}=$ $\left(\mathrm{B}_{0} / \mathrm{B}_{0}{ }^{\prime}\right)\left[\left(\mathrm{V} / \mathrm{V}_{0}\right)^{\left.-\mathrm{B}_{0}{ }^{\prime}-1\right]}\right.$ where $\mathrm{B}_{0}$ is the isothermal bulk modulus, $\mathrm{B}_{0}{ }^{\prime}$ its pressure derivative and $\mathrm{V}_{0}$ and $\mathrm{V}$ are the volume at ambient pressure and pressure $\mathrm{p}$ respectively. Given the similar volume response of $\mathrm{CeNi}_{2} \mathrm{Ge}_{2}$ and $\mathrm{LaMn}_{2} \mathrm{Si}_{2}$ to pressure, we have assumed that the average value of $\mathrm{B}_{0}$ and $\mathrm{B}_{0}$ ' for these $\mathrm{RT}_{2} \mathrm{X}_{2}$ compounds can also be applied to $\mathrm{PrMn}_{2} \mathrm{Ge}_{2}$, with this analysis leading to the full line shown in Fig 18(b). Hence, using our measured values of the unit cell volumes for the series of $\operatorname{PrMn}_{2-\mathrm{x}} \mathrm{Fe}_{\mathrm{x}} \mathrm{Ge}_{2}$ compounds, and assuming that the effects of "chemical" pressure resulting from replacement of $\mathrm{Mn}$ with the smaller Fe atoms is equivalent to compressive pressure, we can identify the theoretical pressure corresponding to the $\operatorname{PrMn}_{2-\mathrm{x}} \mathrm{Fe}_{\mathrm{x}} \mathrm{Ge}_{2}$ compounds. This in turn enables the changes in $T_{C}{ }^{\text {inter }}$ with pressure for $\operatorname{PrMn}_{2-\mathrm{x}} \mathrm{Fe}_{\mathrm{x}} \mathrm{Ge}_{2}$ to be calculated as shown by the dashed line in Fig 18(c). These values were calculated using the value $\mathrm{dT}_{\mathrm{C}}{ }^{\mathrm{inter}} / \mathrm{dp}=-0.2 \mathrm{~K} / \mathrm{kbar}$ for $\mathrm{PrMn}_{2} \mathrm{Ge}_{2}$ as determined by Kawashima et al. [37].

While the $\mathrm{T}_{\mathrm{C}}{ }^{\text {inter }}$ values calculated on the basis of pressure and therefore geometric effects (dashed line in Fig 18(c)) influence the magnetic transition temperature $\mathrm{T}_{\mathrm{C}}{ }^{\text {inter }}$ as expected, comparison with the experimental $\mathrm{T}_{\mathrm{C}}{ }^{\text {inter }}$ values for $\operatorname{PrMn}_{2-\mathrm{x}} \mathrm{Fe}_{\mathrm{x}} \mathrm{Ge}_{2}(\mathrm{x}=0.0,0.2,0.4,0.6$; cf. Figs 12 and 17), shows that changes in the electronic configurations combined with the increase in the concentration of the non-magnetic Fe atoms has a significant effect on the magnetic behaviour overall. 
Further pressure neutron diffraction measurements on the system will allow electronic effects to be isolated from geometric factors, and the influence of replacing magnetic atoms with non-magnetic atoms to be more quantitatively assessed in determining the magnetic behaviour of these compounds. Measurements of the pressure dependence of the unit cell volume and magnetic transition temperatures for $\operatorname{PrMn}_{2} \mathrm{Ge}_{2}$ would allow the geometric factor to be isolated. Substitution of Ge by $\mathrm{Si}$ in $\mathrm{PrMn}_{2} \mathrm{Ge}_{2-\mathrm{x}} \mathrm{Si}_{\mathrm{x}}$ would, in turn, and on correction for the geometric factor, enable the electronic factor contribution to be derived from the influence on the transition temperatures. Finally, the influence of the non-magnetic atoms substitution for magnetic atoms can be determined having isolated the contribution from the geometric and electronic factors.

\section{Conclusions}

The magnetic behaviour and structures of $\operatorname{PrMn}_{2-x} \mathrm{Fe}_{x} \mathrm{Ge}_{2}$ have been determined by magnetic, Mössbauer spectroscopy and powder neutron diffraction measurements. The present findings have enabled the magnetic phase diagram to be extended from Fe concentrations in the range $\mathrm{x}=0-1$ as reported by Dincer et al. [18], to $\mathrm{x}=0$-2. The phases and structures of $\mathrm{PrMn}_{2-\mathrm{x}} \mathrm{Fe}_{\mathrm{x}} \mathrm{Ge}_{2}$ are presented in Fig 12 as a function of concentration with the behaviour of the system in terms of the in-plane Mn-Mn spacing $\mathrm{d}_{\mathrm{Mn}-\mathrm{Mn}}$ shown in Fig 17 . The Mn sublattice exhibits magnetic ordering over the entire concentration range whereas the Pr sublattice orders antiferromagnetically for $\mathrm{PrFe}_{2} \mathrm{Ge}_{2}$ [25] and ferromagnetically at Mn-rich compositions $(\mathrm{x}<\sim 0.8)$. As expected and in agreement with earlier studies, the overall magnetic behaviour of $\mathrm{PrMn}_{2-\mathrm{x}} \mathrm{Fe}_{\mathrm{x}} \mathrm{Ge}_{2}$ compounds is governed by the strong dependence of the magnetic couplings between and, particularly, within the Mn layers [e.g. 1,3]. This is evident from the phase diagram of Fig 17 expressed in terms of the intralayer distance $\mathrm{d}_{\mathrm{Mn}-\mathrm{Mn}}$ and the $a$-lattice parameter. 
The temperature dependences of magnetic hyperfine field and the electric quadrupole interaction parameters change around the reported magnetic phase transitions with the composition dependence of the hyperfine parameters at $4.5 \mathrm{~K}$ (Fig 11) indicating a critical concentration $\mathrm{x}_{\mathrm{c}} \sim 0.8$ for transformation of the Fmc magnetic structure to the AFmc magnetic structure. Analyses of the Mössbauer spectra also confirm that the $\mathrm{Fe}$ atom acts as a nonmagnetic probe in these $\mathrm{RT}_{2} \mathrm{X}_{2}$ compounds with the magnetic hyperfine field revealing reduced values relative to the total magnetic moment values (see for example Fig 8(a)). As shown in Fig 11(d), the Debye temperatures for $\mathrm{PrMn}_{2-\mathrm{x}} \mathrm{Fe}_{\mathrm{x}} \mathrm{Ge}_{2}$ compounds are found to increase with increasing Fe concentration, consistent with the larger Debye temperature for Fe, $\Theta_{D}{ }^{\mathrm{Fe}} \sim 460 \mathrm{~K}$, compared with that of $\mathrm{Mn}, \Theta_{D}{ }^{\mathrm{Mn}} \sim 400 \mathrm{~K}$.

In addition to geometric factors, electronic effects and substitution of magnetic Mn atoms with nonmagnetic Fe atoms influence the magnetic structures in $\operatorname{PrMn}_{2-\mathrm{x}} \mathrm{Fe}_{\mathrm{x}} \mathrm{Ge}_{2}$. This is demonstrated by Fig 18(c) which shows calculated values for $\mathrm{T}_{\mathrm{C}}{ }^{\text {inter }}$ (the transition temperature for transformation from the intralayer antiferromagnetic ordering within the (001) Mn layers of AFl to the canted ferromagnetism of Fmc with both intralayer and interlayer interactions) based on pressure effects alone, compared with the experimental $\mathrm{T}_{\mathrm{C}}{ }^{\text {inter }}$ values for $\mathrm{PrMn}_{2-\mathrm{x}} \mathrm{Fe}_{\mathrm{x}} \mathrm{Ge}_{2}$ compounds with $\mathrm{Fe}$ concentrations in the range $x=0.0$ to 0.6 . The significant deviations in these calculated and experimental $\mathrm{T}_{\mathrm{C}}{ }^{\text {inter }}$ values indicate clearly the combined influence of electronic effects and nonmagnetic Fe atoms on the magnetic behaviour.

As shown, for example, by the behaviour of the $\operatorname{PrMn}_{1.6} \mathrm{Fe}_{0.4} \mathrm{Ge}_{2}$ compound (Fig 14), the anomalous thermal expansion detected in these systems is influenced greatly by the interlayer Mn-Mn interactions. In addition, the unit cell and magnetovolume changes at $\mathrm{T}_{\mathrm{C}}{ }^{\mathrm{Pr}}$ (e.g. Figs 14(a), (b), (c)) reflect the additional contributions from $\mathrm{Mn}-\mathrm{Pr}$ and Pr-Pr magnetic exchange interactions to thermal 
expansion due to the appearance of Pr magnetic ordering. This is likely to play an important role in determining the magnetocaloric properties of these layered compounds as reported recently [33].

\section{Acknowledgements}

This work was supported in part by the Australian Research Council and by grants from the Australian Institute of Nuclear Science and Engineering. We acknowledge financial support from the Access to Major Research Facilities Programme which is a component of the International Science Linkages Programme established under the Australian Government's innovation statement, Backing Australia's Ability. 


\section{References}

[1] A. Szytula and J. Leciejewicz, in Handbook on the Physics and Chemistry of Rare Earths, edited by K. A. Gschneider, Jr. and L. Erwin (Elsevier, Amsterdam, 1989), Vol. 12, p. 133; A. Szytula, J. Leciejewicz, Handbook of Crystal Structures and Magnetic Properties of Rare Earth Intermetallics, CRC Press, Boca Raton, 1994

[2] E. G. Gerasimov and N. V. Mushnikov and T. Goto, Phys. Rev. B 72, 064446 (2005).

[3] G. Venturini, R Welter, J E Ressouche, B. Malaman, J. Magn. Magn. Mater. 150, 197 (1995)

[4] J. H. V. J. Brabers, K. H. J. Buschow and F. R. de Boer, Phys. Rev. B 59, 9314 (1999); T. Fujiwara, H. Fujii and T. Shigeoka, Phys. Rev. B 63, 174440 (2001)

[5] M. Hofmann, S.J. Campbell, A.V.J. Edge, Phys. Rev. B 69, 174432 (2004)

[6] S. Kervan, A. Kilic and A. Gencer, J. Phys.: Condens. Matter 16, 4955 (2004)

[7] K. Sengupta, P.L. Paulose, E.V. Sampathkumaran, T. Doert, and J.P.F. Jemetio, Phys. Rev. B 72, $184424(2005)$.

[8] I Dincer, A Elmali, Y Elerman, H Ehrenberg, H Fuess, A Daoud-Aladine, J. Alloy. Comp. 403, 53 (2005);

[9] I Dincer, Y Elerman, A Elmali, H Ehrenberg, G André, J. Magn. Magn. Mater. 313, 342 (2007)

[10] S.J. Campbell, J.M. Cadogan, X.L. Zhao, M. Hofmann and H.S. Li, J. Phys.: Condens. Matter 11, 7835 (1999).

[11] R. Weiter, G. Venturini, E. Ressouche and B. Malaman, J. Alloy. Comp. 218, 204 (1995)

[12] I Dincer, Y Elerman, A Elmali, H Ehrenberg, H Fuess, H Duman, M Acet, J. Magn. Magn. Mater. 248, 268 (2002)

[13] L. Morellon, P. A. Algarabel, M. R. Ibarra and C. Ritter, Phys. Rev. B 55, 12363 (1997)

[14] J.L. Wang, S.J. Campbell, J.M. Cadogan, O. Tegus, A J Studer and M Hofmann, J. Phys.: Condens. Matter 18, 189 (2006); J.L. Wang, A J Studer, S.J. Campbell, M Hofmann and J.M. Cadogan, Physica B 385-386, 326 (2006) 
[15] I. Ijjaali, G. Venturini, B. Malaman, E. Ressouch, J. Alloy. Comp. 266, 61 (1998)

[16] Siek S, Szytula A and J. Leciewicz Solid State Commun. 39, 863 (1981)

[17] J. H. V. J. Brabers, A. J. Nolten, F. Kayzel, S. H. J. Lenczowski, K. H. J. Buschow, and F. R. de Boer, Phys. Rev. B 50, 16410 (1994)

[18] I. Dincer, A. Elmali, Y. Elerman, H. Ehrenberg, H. Fuess and G. Andre, J. Alloy. Comp. 416, $22(2006)$

[19] S. Kervan, Y. Elerman, A. Elmali and R. Theissmann, J. Alloy. Comp. 327, 27 (2001)

[20] I. Dincer, A. Elmali, Y. Elerman, H. Ehrenberg, H. Fuess and O. Isnard, J. Phys.: Condens. Matter 16, 2081 (2004)

[21] G J Tomka, C Ritter, P C Riedi, Cz Kaputska, W Kocemba, Phys. Rev. B 58, 6330 (1998)

[22] Juan Rodriguez-Carvajal, The XV-th Congr. Int. Union of Crystallography, Proceedings of the Satellite Meeting On Powder Diffraction, Toulouse, France (1990), p 127; http://www1lb.cea.fr/fullweb/

[23] L. Gelato, J. Appl. Crystallogr. 14, 151 (1981)

[24] A. Szytula, J. Leciejewicz, in Handbook on Crystal Structures and Magnetic Properties of Rare Earth Intermetallics, (CRC Press, USA) 1994

[25] B. Malaman, G. Venturini, A. Blaise, J.P. Sanchez, and G. Amoretti, Phys. Rev. B 47, 8681 (1993)

[26] I. Nowik, Y. Levi, I. Felner and E.R. Bauminger, J. Magn. Magn. Mater. 147, 373 (1995)

[27] M. Hofmann, S.J. Campbell, A. Szytula, J. Alloy. Comp. 311, 137 (2000)

[28] G K Shenoy, F E Wagner, G M Kalvius, in Mössbauer Isomer Shifts eds G K Shenoy, F E Wagner, (North-Holland, Amsterredam, 1978) p 49

[29] J. Cies'lak, S. M. Dubiel, J. Zukrowski, M. Reissner and W. Steiner, Phys. Rev. B 65, 212301 (2002) 
[30] G.J. Long, D. Hautot, F. Grandjean, D.T. Morelli and G.P. Meisner, Phys. Rev. B 60, 7410 (1999)

[31] http://www.infoplease.com/periodictable.php

[32] P. Kumar, K.G. Suresh, A.K. Nigam, A. Magnus, A.A. Coelho, and S. Gama, Phys. Rev B 77, $224427(2008)$

[33] R. Zeng, J. L Wang, L. Lu, W.X. Li, S.J. Campbell and S. X. Dou (in preparation, 2008)

[34] S. Di Napoli, A. M. Llois, G. Bihlmayer and S. Blügel, Phys. Rev. B 75, 104406 (2007)

[35] T. Fukuhara, K. Maezawa, H. Ohkuni, T. Kagayama and G. Oomi, Physica B 230-232, 198 (1997)

[36] M. Hofmann, S.J. Campbell, K. Knorr, S. Hull and V. Ksenofontov, J. Appl. Phys. 91, 8126 (2002)

[37] T. Kawashima, T. Kanomata, H. Yoshida and T. Kaneko, J. Magn. Magn. Mater. 90-91, 721 (1990) 
Table I Lattice parameters and structural information for the $\mathrm{PrMn}_{2-\mathrm{x}} \mathrm{Fe}_{\mathrm{x}} \mathrm{Ge}_{2}$ compounds at room temperature as derived from Rietveld refinements of the x-ray diffraction patterns (e.g. Fig 1) (the errors for the lattice parameters $a$ and $c$, and the interatomic spacing distances, were derived to be $\pm 0.001 \AA$ from the data fits; $\left.z_{\mathrm{Ge}}, \pm 0.001\right)$.

\begin{tabular}{|c|c|c|c|c|c|c|c|c|}
\hline Fe & $\mathrm{x}=0$ & $\mathrm{x}=0.4$ & $\mathrm{x}=0.6$ & $\mathrm{x}=0.8$ & $\mathrm{x}=1.0$ & $\mathrm{x}=1.3$ & $\mathrm{x}=1.6$ & $\mathrm{x}=2.0$ \\
\hline$a(\AA)$ & 4.12 & 4.100 & 4.088 & 4.082 & 4.072 & 4.069 & 4.060 & 4.057 \\
\hline$c(\AA)$ & 10.93 & 10.869 & 10.834 & 10.813 & 10.763 & 10.712 & 10.630 & 10.517 \\
\hline$V\left(\AA^{3}\right)$ & 186 & 182.7 & 181.1 & 180.1 & 178.5 & 177.3 & 175.2 & 173.2 \\
\hline$c / a$ & 2.649 & 2.651 & 2.650 & 2.649 & 2.643 & 2.633 & 2.618 & 2.592 \\
\hline$d_{M n-M n}(\AA)$ & 2.92 & 2.899 & 2.891 & 2.866 & 2.879 & 2.877 & 2.871 & 2.869 \\
\hline$d_{M n-P r}(\AA)$ & 3.42 & 3.404 & 3.393 & 3.387 & 3.374 & 3.363 & 3.344 & \\
\hline$d_{P r-P r}(\AA)$ & 4.12 & 4.10 & 4.088 & 4.082 & 4.072 & 4.069 & 4.060 & 4.057 \\
\hline$[$ Reference $]$ & {$[11]$} & & & & & & & {$[25]$} \\
\hline
\end{tabular}


Table II Structural and magnetic parameters as derived from Rietveld refinements of the neutron diffraction patterns for $\operatorname{PrMn}_{2-\mathrm{x}} \mathrm{Fe}_{\mathrm{x}} \mathrm{Ge}_{2}$ with $\mathrm{x}=0.4$ and 1.3 at selected temperatures. $\mu_{\text {total }}$ - the total Mn moment; $\mu_{a b}$ - the Mn moment in (001) Mn layers; $\mu_{z}$ - the Mn moment along the $c$-axis; $\mu_{\mathrm{Pr}}$ the Pr moment along the $c$-axis.

\begin{tabular}{|c|c|c|c|c|c|c|}
\hline Fe & $\mathrm{x}=0.4$ & $\mathrm{x}=0.4$ & $\mathrm{x}=0.4$ & $\mathrm{x}=0.4$ & $\mathrm{x}=1.3$ & $\mathrm{x}=1.3$ \\
\hline $\mathrm{T}(\mathrm{K})$ & $20 \mathrm{~K}$ & $180 \mathrm{~K}$ & $300 \mathrm{~K}$ & $410 \mathrm{~K}$ & $3 \mathrm{~K}$ & $300 \mathrm{~K}$ \\
\hline $\mathrm{a}(\AA)$ & 4.094 & 4.096 & 4.102 & 4.105 & 4.060 & 4.070 \\
\hline $\mathrm{c}(\AA)$ & 10.879 & 10.868 & 10.874 & 10.887 & 10.667 & 10.710 \\
\hline $\mathrm{Z}_{\mathrm{Ge}}$ & 0.380 & 0.382 & 0.381 & 0.382 & 0.378 & 0.379 \\
\hline$\mu_{\mathrm{ab}(} \mu_{\mathrm{B})}$ & 2.61 & 2.41 & 1.73 & - & 0.33 & - \\
\hline$\mu_{\mathrm{Z}\left(\mu_{\mathrm{B}}\right)}$ & 2.85 & 2.49 & - & - & 1.21 & - \\
\hline$\mu_{\mathrm{total}}\left(\mu_{\mathrm{B})}\right.$ & 3.86 & 3.46 & 1.73 & - & 1.25 & - \\
\hline$\mu_{\mathrm{Pr}(}\left(\mu_{\mathrm{B})}\right.$ & 1.76 & - & - & - & - & - \\
\hline $\mathrm{R}_{\mathrm{wp}}$ & 7.6 & 6.9 & 4.8 & 5.1 & 6.9 & 10.9 \\
\hline $\mathrm{R}_{\exp }$ & 5.4 & 5.3 & 5.4 & 5.4 & 2.9 & 7.1 \\
\hline$\chi^{2}$ & 2.0 & 1.7 & 0.8 & 0.9 & 5.8 & 2.3 \\
\hline & & & & & & \\
\hline
\end{tabular}




\section{Figure captions:}

Fig. 1 (Color online) X-ray diffraction patterns for $\operatorname{PrMn}_{2-\mathrm{x}} \mathrm{Fe}_{\mathrm{x}} \mathrm{Ge}_{2}$ compounds with $\mathrm{x}=0.4,0.8,1.3$ and $1.6(\mathrm{Cu}-\mathrm{K} \alpha$ radiation; $\lambda=1.5418 \AA)$.

Fig. 2 (Color online) The temperature dependences of magnetisation (full symbol) and inverse magnetisation (open symbol) for $\operatorname{PrMn}_{1.0} \mathrm{Fe}_{1.0} \mathrm{Ge}_{2.0}$ as measured in a magnetic field of $\mathrm{H}=50$ Oe.

Fig. 3 (Color online) (a) The temperature dependences of magnetisation (full symbol) and inverse magnetisation (open symbol) for $\operatorname{PrMn}_{0.7} \mathrm{Fe}_{1.3} \mathrm{Ge}_{2.0}$ as measured in a magnetic field of $\mathrm{H}=50$ Oe. The inset shows the $\mathrm{dM} / \mathrm{dT}$ versus $\mathrm{T}$ curve over the temperature range $70 \mathrm{~K}-118 \mathrm{~K}$ to identify $\mathrm{T}_{\mathrm{N}}{ }^{\text {intra }}$ more clearly.

(b) The variation of magnetization with applied magnetic field $\left(\mathrm{H}_{\mathrm{appl}}=0-50 \mathrm{kOe}\right)$ for $\operatorname{PrMn}_{0.7} \mathrm{Fe}_{1.3} \mathrm{Ge}_{2.0}$ at the temperatures indicated.

(c) Arrot plot $\left(\mathrm{M}^{2}\right.$ versus $\left.\mathrm{H} / \mathrm{M}\right)$ for $\operatorname{PrMn}_{0.7} \mathrm{Fe}_{1.3} \mathrm{Ge}_{2.0}$ at the temperatures indicated.

Fig. 4 (Color online) (a) The temperature dependences of magnetisation (full symbol) and inverse magnetisation (open symbol) for $\mathrm{PrMn}_{0.4} \mathrm{Fe}_{1.6} \mathrm{Ge}_{2.0}$ as measured in a magnetic field of $\mathrm{H}=$ 100 Oe.

(b) The variation of magnetization with applied magnetic field $\left(\mathrm{H}_{\mathrm{appl}}=0-50 \mathrm{kOe}\right)$ for $\operatorname{PrMn}_{0.4} \mathrm{Fe}_{1.6} \mathrm{Ge}_{2.0}$ at the temperatures indicated.

(c) The corresponding Arrot-plot $\left(\mathrm{M}^{2}\right.$ versus $\left.\mathrm{H} / \mathrm{M}\right)$ at the temperatures indicated.

Fig. $5{ }^{57} \mathrm{Fe}$ Mössbauer spectra of $\operatorname{PrMn}_{1.0} \mathrm{Fe}_{1.0} \mathrm{Ge}_{2.0}$ over the temperature range 4.5 - $300 \mathrm{~K}$. All 
of the spectra have been fitted with five sextets with fractional areas of $0.063,0.250,0.375$, 0.250 and 0.063 . These sextets represent Fe atoms with zero, one, two, three and four nearest-neighbour Fe atoms respectively. Examples of the subspectral components are shown in the $4.5 \mathrm{~K}$ spectra.

Fig. $6{ }^{57} \mathrm{Fe}$ Mössbauer spectra of $\operatorname{PrMn}_{0.7} \mathrm{Fe}_{1.3} \mathrm{Ge}_{2.0}$ over the temperature range $4.5-300 \mathrm{~K}$. All of the spectra have been fitted with five sextets with fractional areas of $0.015,0.111,0.311$, 0.384 and 0.179 . These sextets represent Fe atoms with zero, one, two, three and four nearest-neighbour Fe atoms respectively. Examples of the subspectral components are shown in the $4.5 \mathrm{~K}$ spectra.

Fig. $7{ }^{57} \mathrm{Fe}$ Mössbauer spectra of $\operatorname{PrMn}_{0.4} \mathrm{Fe}_{1.6} \mathrm{Ge}_{2.0}$ over the temperature range $4.5-300 \mathrm{~K}$. All of the spectra have been fitted with four sextets with fractional areas of $0.026,0.154,0.410$ and 0.410. These sextets represent Fe atoms with one, two, three and four nearest-neighbour Fe atoms respectively. Examples of the subspectral components are shown in the $4.5 \mathrm{~K}$ spectra.

Fig. 8 (Color online) Temperature dependences of the Mössbauer hyperfine parameters of $\operatorname{PrMn}_{1.0} \mathrm{Fe}_{1.0} \mathrm{Ge}_{2.0}$ :

(a) $\left\langle\mathrm{B}_{\mathrm{hf}}>\right.$, the average magnetic hyperfine field (open triangle) and total $\mathrm{Mn}$ magnetic moments (full symbol) derived from [18]; (b) quadrupole shift $\varepsilon$ and (c) isomer shift $\delta$. The lines in (a) and (b) represent guides to the eye; the arrows show $\mathrm{T}_{\mathrm{N}}{ }^{\text {inter }} \sim 140 \mathrm{~K}$ and $\mathrm{T}_{\mathrm{N}}{ }^{\text {intra }} \sim$ $208 \mathrm{~K}$ as determined from the magnetisation curve shown in Fig 2. The full line in (c) represents the best fit to equation (2) resulting in the Debye temperature $\theta_{D}=380 \pm 20 \mathrm{~K}$. 
Fig. 9 (Color online) Temperature dependences of the Mössbauer hyperfine parameters of $\operatorname{PrMn}_{0.7} \mathrm{Fe}_{1.3} \mathrm{Ge}_{2.0}$ :

(a) $<\mathrm{B}_{\mathrm{hf}}>$, the average magnetic hyperfine field; (b) quadrupole shift $\varepsilon$ and (c) isomer shift $\delta$. The lines in (a) and (b) represent guides to the eye; the arrows show $\mathrm{T}_{\mathrm{N}}{ }^{\text {inter }} \sim 56 \mathrm{~K}$ and $\mathrm{T}_{\mathrm{N}}{ }^{\text {intra }}$ $\sim 103 \mathrm{~K}$ as determined from the magnetisation curve shown in Fig 3(a). The full line in (c) represents the best fit to equation (2) resulting in the Debye temperature $\theta_{D}=400 \pm 20 \mathrm{~K}$.

Fig. 10 (Color online) Temperature dependences of the Mössbauer hyperfine parameters of $\operatorname{PrMn}_{0.4} \mathrm{Fe}_{1.6} \mathrm{Ge}_{2.0}$ :

(a) $<\mathrm{B}_{\mathrm{hf}}>$, the average magnetic hyperfine field; (b) quadrupole shift $\varepsilon$ and (c) isomer shift $\delta$. The lines in (a) and (b) represent guides to the eye; the arrows show $\mathrm{T}_{\mathrm{N}}{ }^{\text {inter }} \sim 38 \mathrm{~K}$ and $\mathrm{T}_{\mathrm{N}}{ }^{\text {intra }}$ $\sim 66 \mathrm{~K}$ as determined from the magnetisation curve shown in Fig 4(a). The full line in (c) represents the best fit to equation (2) resulting in the Debye temperature $\theta_{D}=420 \pm 20 \mathrm{~K}$ indicated.

Fig. 11 (Color online) The Mössbauer hyperfine parameters of $\operatorname{PrMn}_{2-\mathrm{x}} \mathrm{Fe}_{\mathrm{x}} \mathrm{Ge}_{2}$ compounds at $4.5 \mathrm{~K}$ and the calculated Debye temperatures $\theta_{D}$ as functions of Fe concentration, $\mathrm{x}$. The $\theta_{D}$ values for $\operatorname{PrMn}_{2-\mathrm{x}} \mathrm{Fe}_{\mathrm{x}} \mathrm{Ge}_{2}$ with $\mathrm{x}=0.4,0.6$ and 0.8 were obtained by analysing our earlier isomer shift [14] and the values for $\operatorname{PrMn}_{2} \mathrm{Fe}_{2}(\mathrm{x}=2.0$, open symbols) were taken from [25].

(a) $\left\langle\mathrm{B}_{\mathrm{hP}}>\right.$ average magnetic hyperfine field;

(b) quadrupole shift $\varepsilon$;

(c) isomer shift $\delta$;

(d) Debye temperatures, $\theta_{D}$. 
Fig. 12 (Color online) The magnetic phase diagram of $\operatorname{PrMn}_{2-\mathrm{x}} \mathrm{Fe}_{\mathrm{x}} \mathrm{Ge}_{2}$ as a function of Fe concentration $\mathrm{x}$. The region for $0 \leq \mathrm{x} \leq 1$ is reproduced from [18] (full symbols) with extension to the magnetic phase diagram for $1 \leq \mathrm{x} \leq 2$ based on the present data (open symbols, see also [14]). The PM/AFl and AF1/AFmc boundaries delineating the regions of the Mn-sublattice for the $\operatorname{PrMn}_{0.4} \mathrm{Fe}_{1.6} \mathrm{Ge}_{2}$ compound have been extrapolated (dashed lines) to the antiferromagnetism of the pure $\mathrm{PrFe}_{2} \mathrm{Ge}_{2}$ compound of $\mathrm{T}_{\mathrm{N}}=14 \mathrm{~K}$ [25]. The dot-dash line shows the low temperature boundary between $\mathrm{Fmc}+\mathrm{F}(\mathrm{Pr})$ and $\mathrm{AFmc}$ determined from the present hyperfine parameters (Fig 11). The boundary separating the Fmi and Fmc phases has been extrapolated (dotted line) into the region of combined ferromagnetic ordering for the Mn- and Pr-sublattices. The transition temperatures determined from the present investigation for $\operatorname{PrMn}_{2-x} \mathrm{Fe}_{x} \mathrm{Ge}_{2}$ compounds in the range $0 \leq \mathrm{x} \leq 1$ agree well with the results of Dincer $e t$ al. [18].

Figs. 13 (Color online) (a)-(d) Neutron diffraction patterns of $\operatorname{PrMn}_{1.6} \mathrm{Fe}_{0.4} \mathrm{Ge}_{2}$ at the temperatures indicated $(\lambda=1.6660 \AA$; MRPD, ANSTO). The full line represents the Rieveld refinement to the data with the peak markers as indicated (a small contribution from the Ti sample holder is also present at $2 \theta \sim 38.1^{\circ}$ ). (e) and (f) show expanded $2 \theta$ ranges for the temperatures indicated.

Fig. 14 (Color online) The variation of: (a) lattice parameter $a$; (b) lattice parameter $c$; (c) unit cell volume V and c/a; (d) the magnetic moments for $\operatorname{PrMn}_{1.6} \mathrm{Fe}_{0.4} \mathrm{Ge}_{2.0}$ as determined by neutron diffraction measurements over the temperature range $\sim 20-410 \mathrm{~K}$. The $\mathrm{M}_{\mathrm{x}}$ and $\mathrm{M}_{\mathrm{z}}$ components of the total magnetic moment are also shown in Fig 14(d). (e) The temperature dependence of magnetisation for $\operatorname{PrMn}_{1.6} \mathrm{Fe}_{0.4} \mathrm{Ge}_{2.0}$ as a reference for the magnetic ordering temperatures $\mathrm{T}_{\mathrm{C}}{ }^{\text {inter }}$ and $\mathrm{T}_{\mathrm{C}}{ }^{\mathrm{Pr}}[14]$. The arrows show $\mathrm{T}_{\mathrm{C}}{ }^{\mathrm{Pr}} \sim 30 \mathrm{~K}, \mathrm{~T}_{\mathrm{C}}{ }^{\text {inter }} \sim 230 \mathrm{~K}$ and $\mathrm{T}_{\mathrm{N}}{ }^{\text {intra }} \sim$ $370 \mathrm{~K}$. 
Fig. 15 (Color online) Neutron diffraction patterns of $\operatorname{PrMn}_{1.2} \mathrm{Fe}_{0.8} \mathrm{Ge}_{2}$ at the temperatures indicated $(\lambda=1.6660 \AA$; MRPD, ANSTO). The full line represents the Rieveld refinement to the $3 \mathrm{~K}$ data with the peak markers as indicated.

Fig. 16 (Color online) Neutron diffraction patterns of $\operatorname{PrMn}_{0.7} \mathrm{Fe}_{1.3} \mathrm{Ge}_{2}$ at (a) $3 \mathrm{~K}$ and (b) $300 \mathrm{~K}(\lambda=$ $1.5487 \AA$; SPODI, FRM-II). The full line represents the Rieveld refinement to the $3 \mathrm{~K}$ data with the peak markers as indicated. Fig 16 (c) shows expanded $2 \theta$ ranges at the temperatures indicated for $\operatorname{PrMn}_{0.7} \mathrm{Fe}_{1.3} \mathrm{Ge}_{2}$.

Fig. 17 (Color online) The magnetic phase diagram of $\operatorname{PrMn}_{2-x} \mathrm{Fe}_{x} \mathrm{Ge}_{2}$ as functions of the in-plane Mn-Mn spacing $\mathrm{d}^{\mathrm{a}}{ }_{\mathrm{Mn}-\mathrm{Mn}}$ and the $a$-lattice parameter at room temperature (symbols: square for $\mathrm{T}_{\mathrm{N}}{ }^{\text {intra }}$; circle for $\mathrm{T}_{\mathrm{C}}{ }^{\text {inter }}$; up triangle for $\mathrm{T}_{\mathrm{N}}{ }^{\text {inter }}$; down triangle for $\mathrm{T}_{\mathrm{C}}{ }^{\mathrm{Pr}}$ and star for $\mathrm{T}_{\mathrm{N}}{ }^{\mathrm{Pr}}[25]$ ). The region for $0 \leq \mathrm{x} \leq 1$ is reproduced from [18] (full symbols) with extension to the magnetic phase diagram for $1 \leq \mathrm{x} \leq 2$ based on the present data (open symbols, see also [14]) as explained in the caption for Fig 12.

Fig. 18 (Color online) (a) Changes in unit cell volume with pressure (normalised to unity at $p=0$ ) derived by the Murnaghan equation $\mathrm{p}=\left(\mathrm{B}_{0} / \mathrm{B}_{0}{ }^{\prime}\right)\left[\left(\mathrm{V} / \mathrm{V}_{0}\right)^{-\mathrm{B}}{ }_{0}-1\right]$ for the $\mathrm{RT}_{2} \mathrm{X}_{2}$ compounds $\mathrm{CeNi}_{2} \mathrm{Ge}_{2}$ [35] (full line) and $\mathrm{LaMn}_{2} \mathrm{Si}_{2}$ [36] (dashed line). $\mathrm{B}_{0}$ is the isothermal bulk modulus and $\mathrm{B}_{0}{ }^{\prime}$ its pressure derivative; $\mathrm{V}_{0}$ and $\mathrm{V}$ are the volume at ambient pressure and pressure $\mathrm{p}$ respectively.

(b) The calculated pressure dependence of the reduced unit cell volume for $\mathrm{PrMn}_{2} \mathrm{Ge}_{2}$ based on the average value of $\mathrm{B}_{0}$ and $\mathrm{B}_{0}^{\prime}$ for the $\mathrm{CeNi}_{2} \mathrm{Ge}_{2}$ and $\mathrm{LaMn}_{2} \mathrm{Si}_{2}$ compounds of Fig 18(a). 
The corresponding $\mathrm{p}$ values have been determined for the series of $\operatorname{PrMn}_{2-x} \mathrm{Fe}_{x} \mathrm{Ge}_{2}$ compounds of measured unit cell volumes as identified in the figure (full triangular symbols). (c) $\mathrm{T}_{\mathrm{C}}{ }^{\text {inter }}$ as a function of Fe composition for $\operatorname{PrMn}_{2-x} \mathrm{Fe}_{x} \mathrm{Ge}_{2}$ : the dashed line shows the calculated $\mathrm{T}_{\mathrm{C}}{ }^{\text {inter }}$ values (using $\mathrm{dT}_{\mathrm{C}}{ }^{\text {inter }} / \mathrm{dp}=-0.2 \mathrm{~K} / \mathrm{kbar}$ for $\operatorname{PrMn}_{2} \mathrm{Ge}_{2}$ [36]) for comparison with the experimental $\mathrm{T}_{\mathrm{C}}{ }^{\text {inter }}$ values (full square symbols) for $\mathrm{x}=0.0,0.2,0.4,0.6$ as in Figs 12 and 17. 


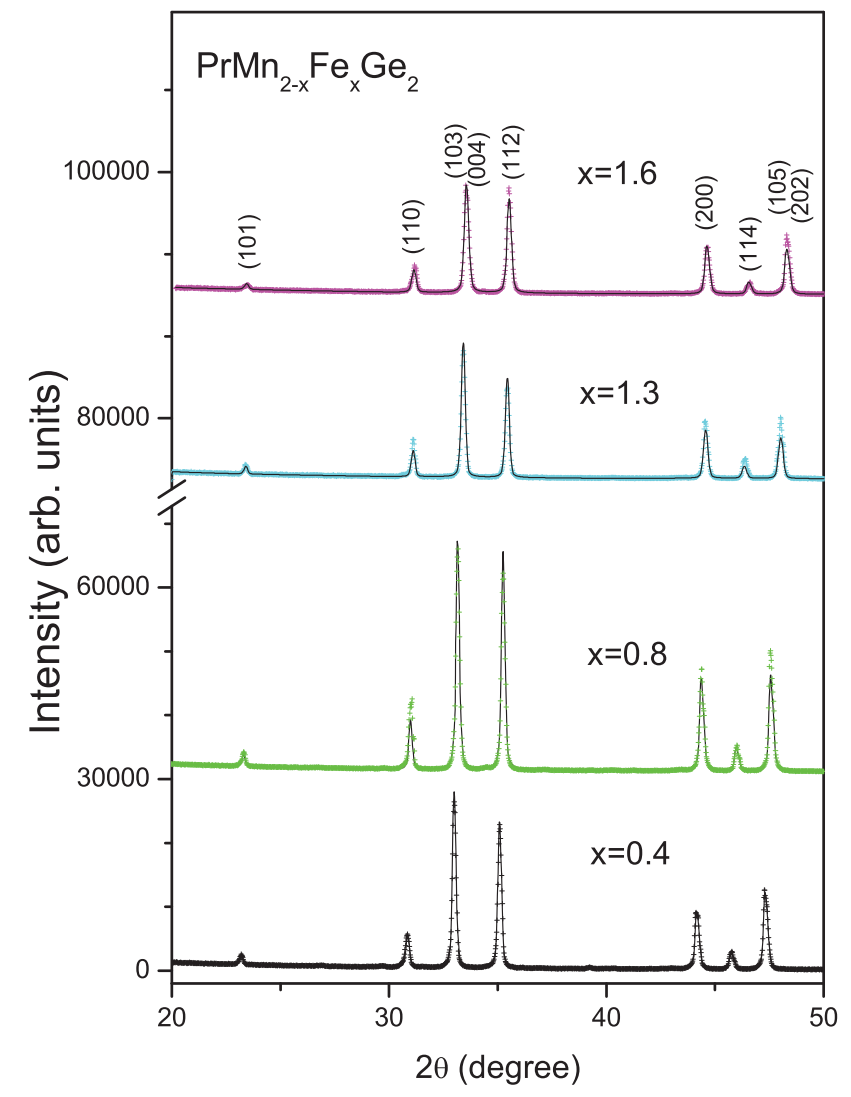




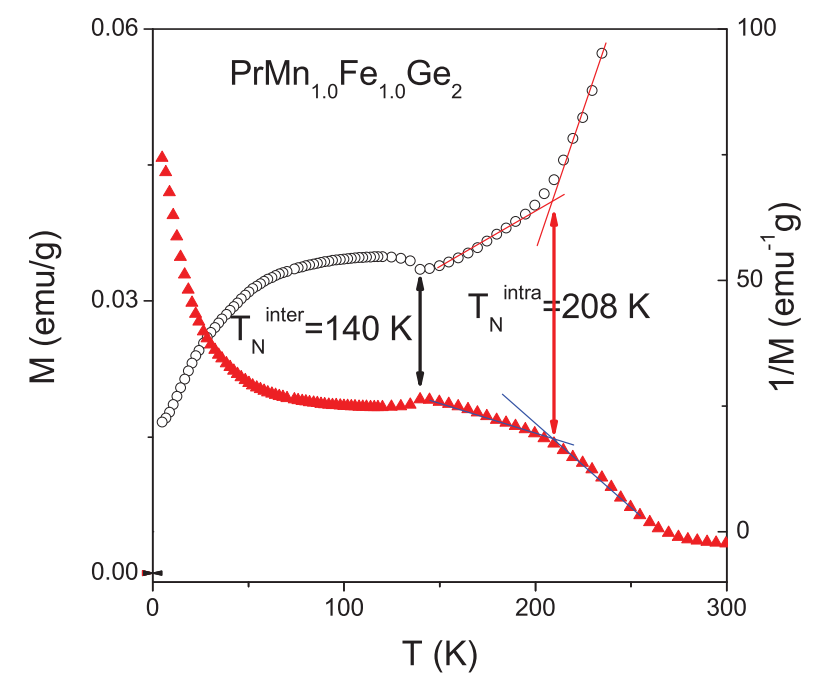



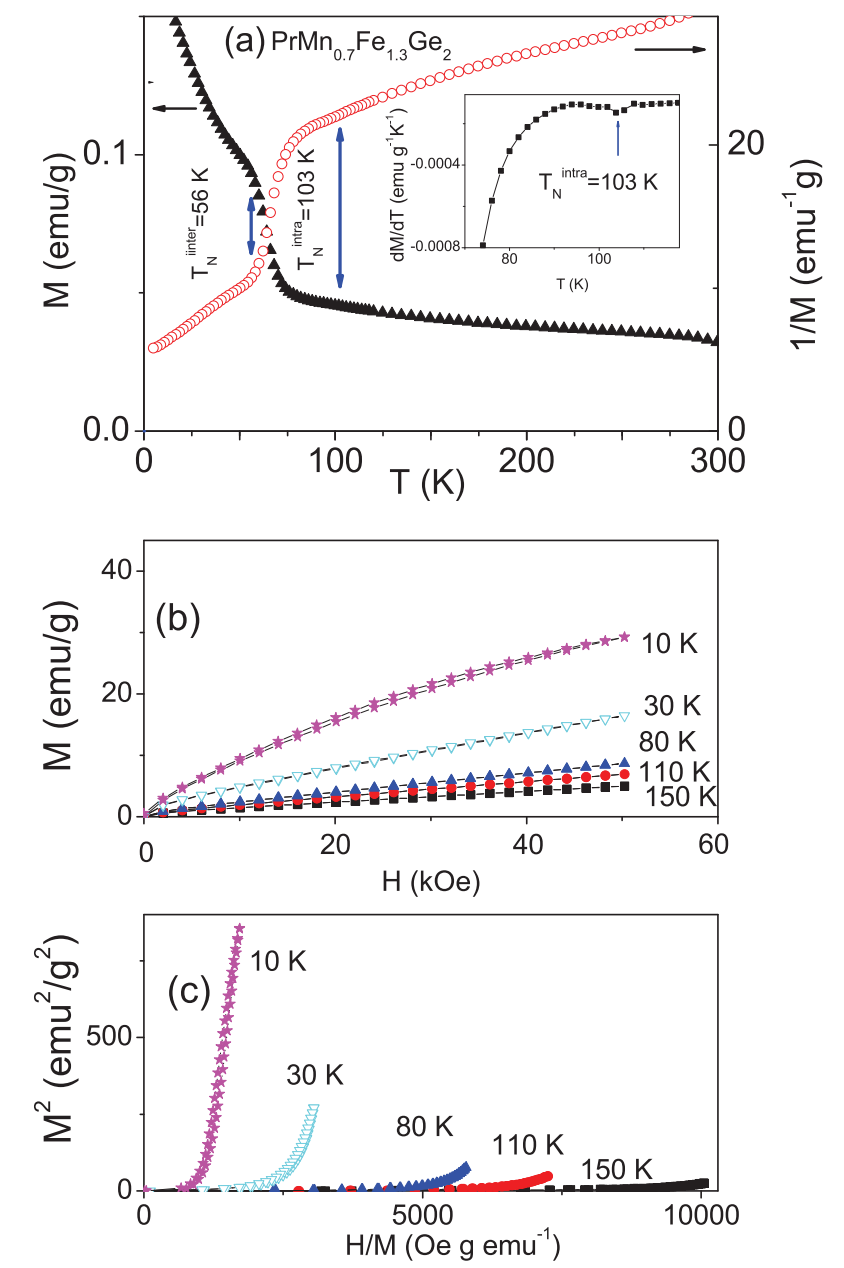


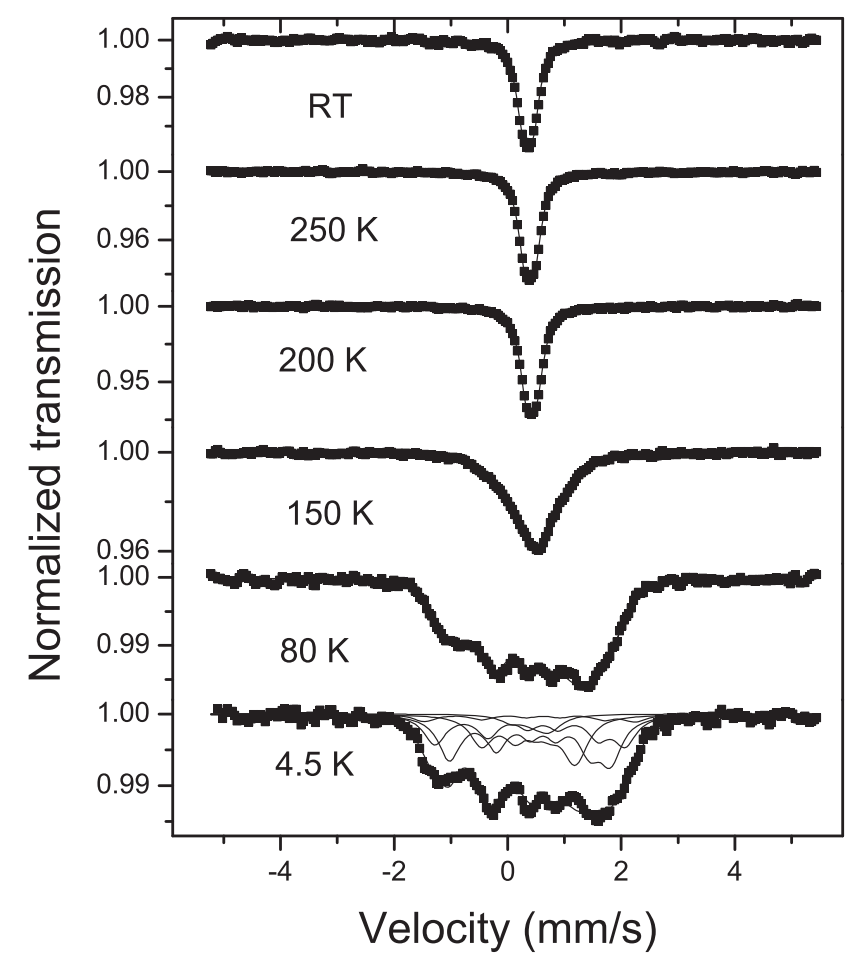




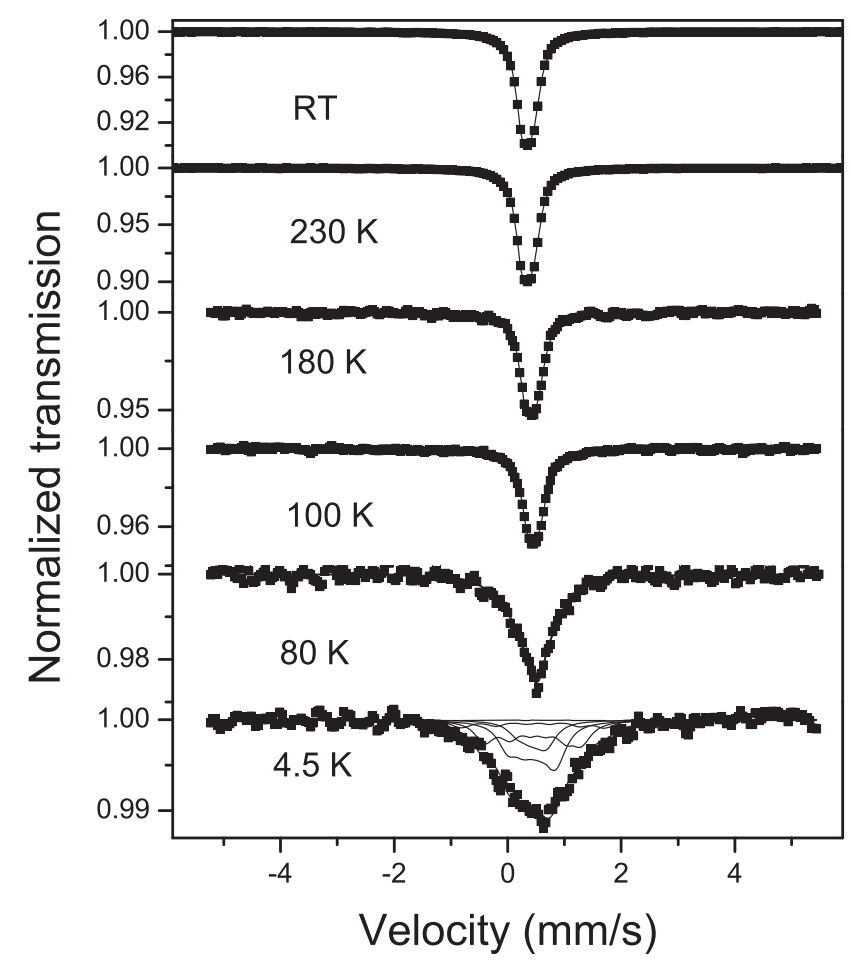




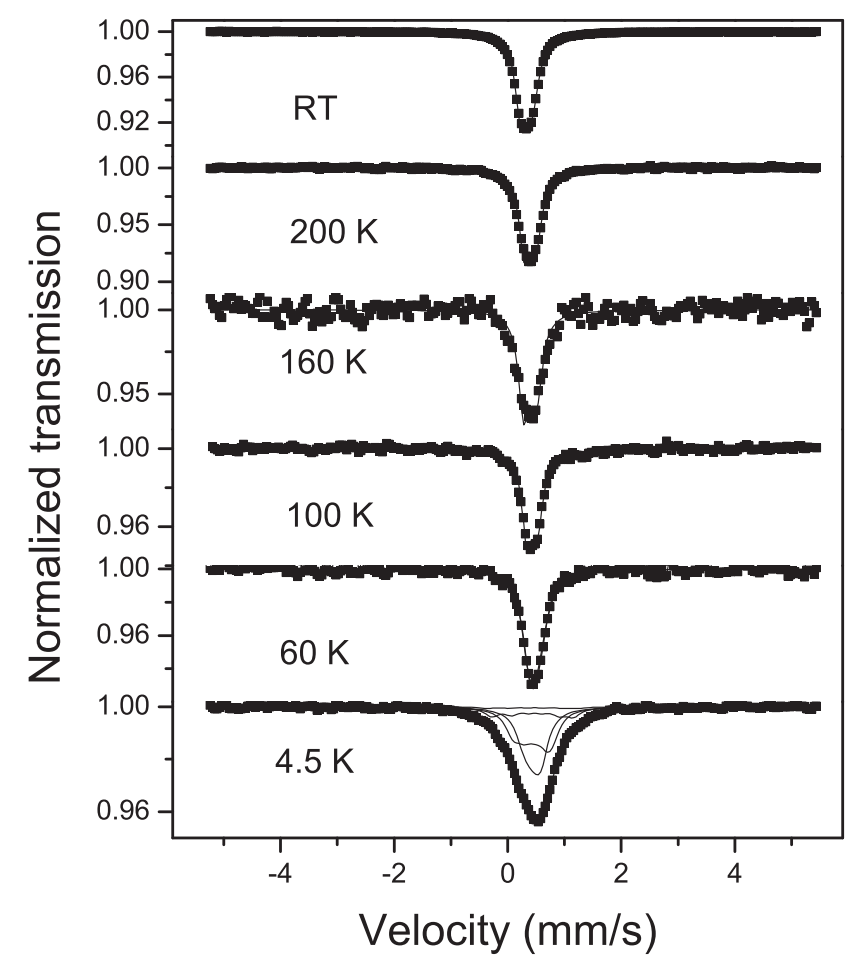




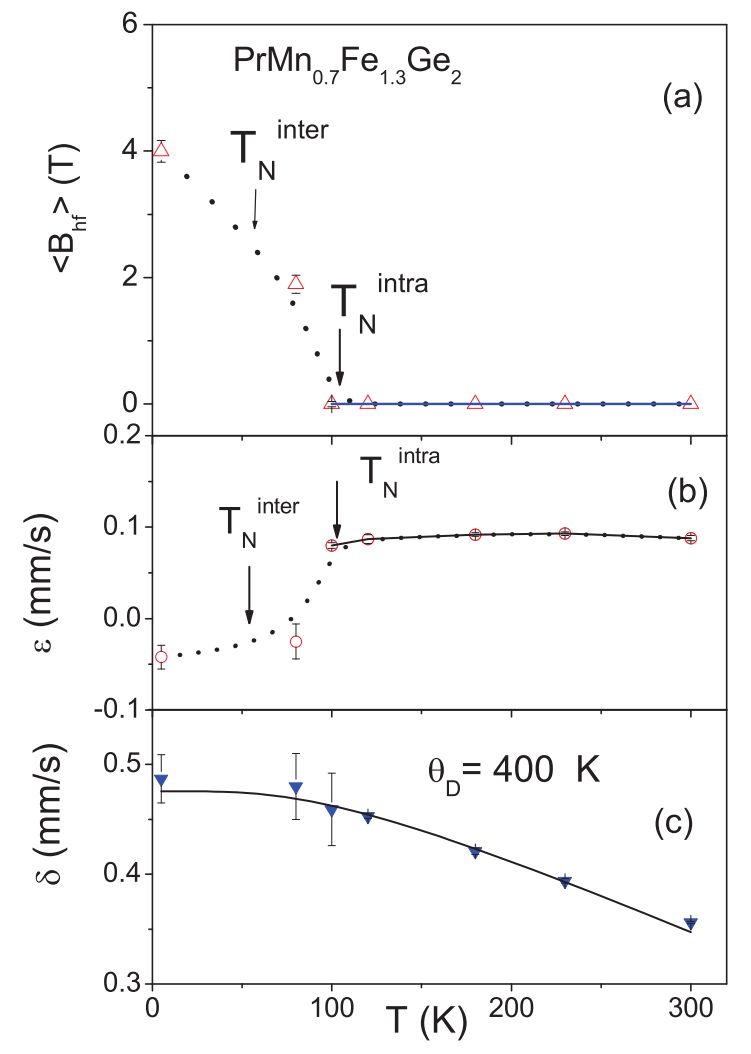




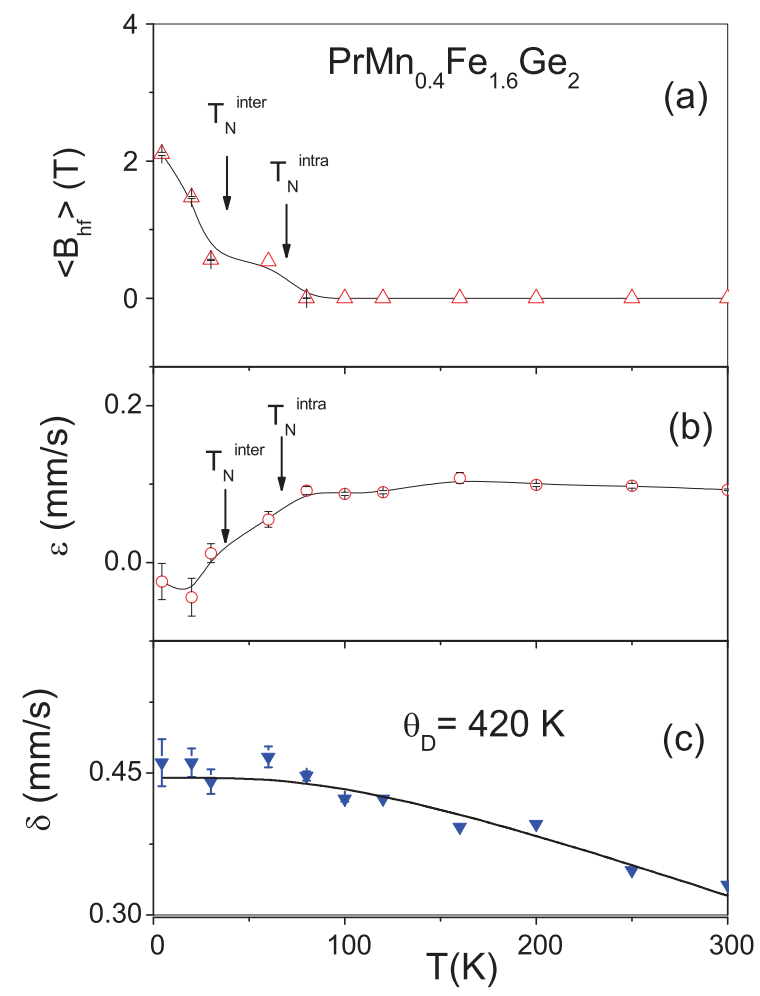




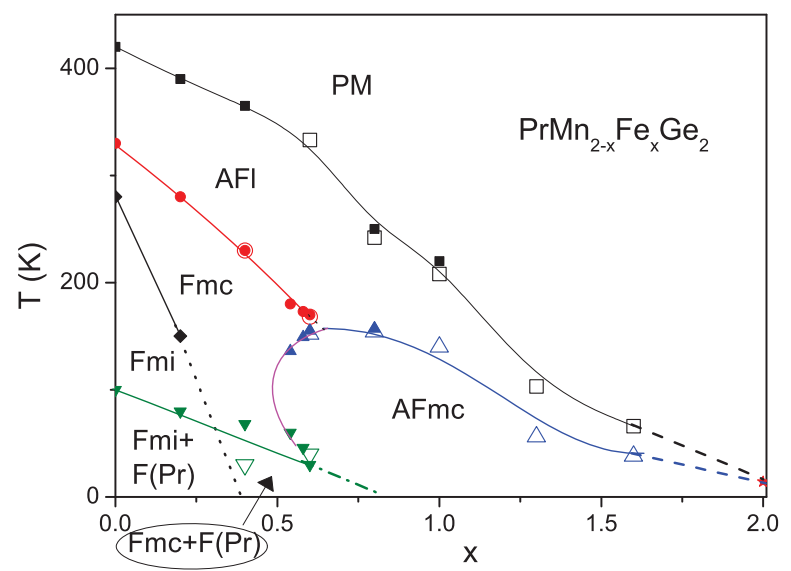



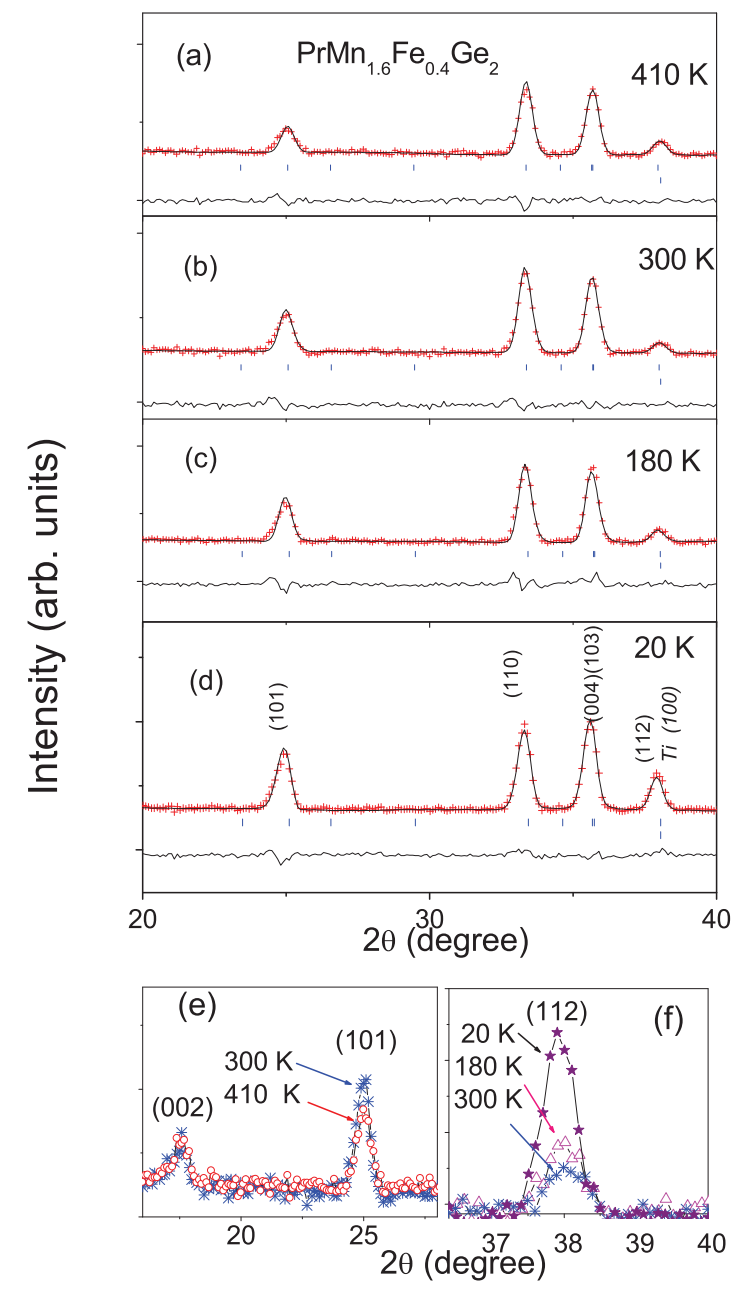


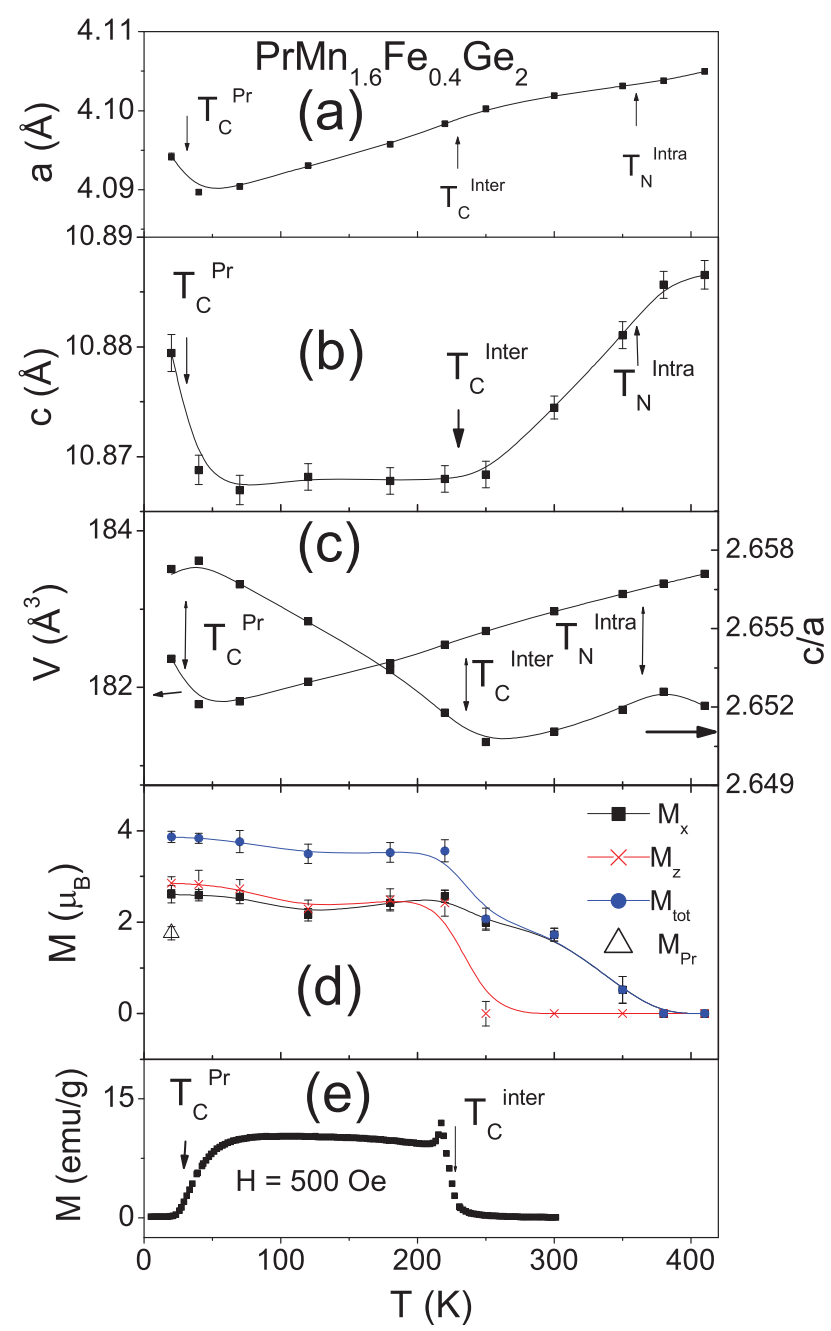




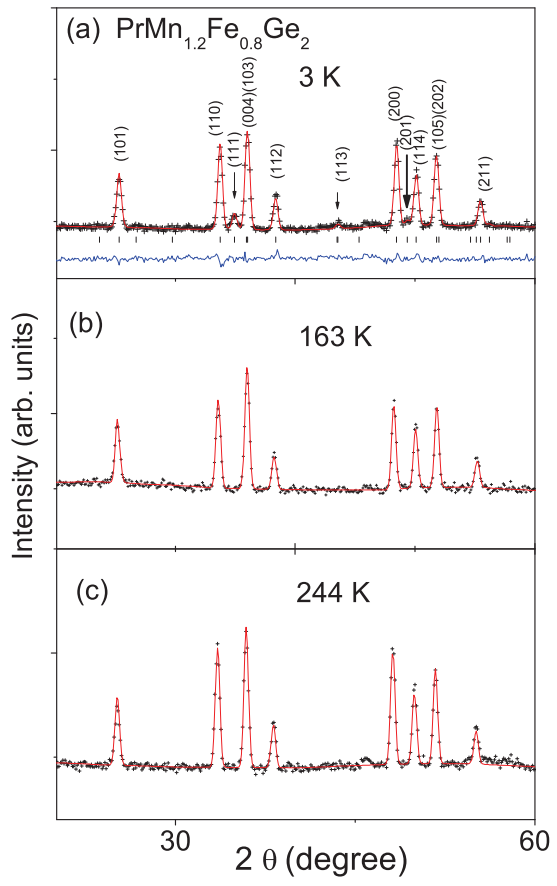



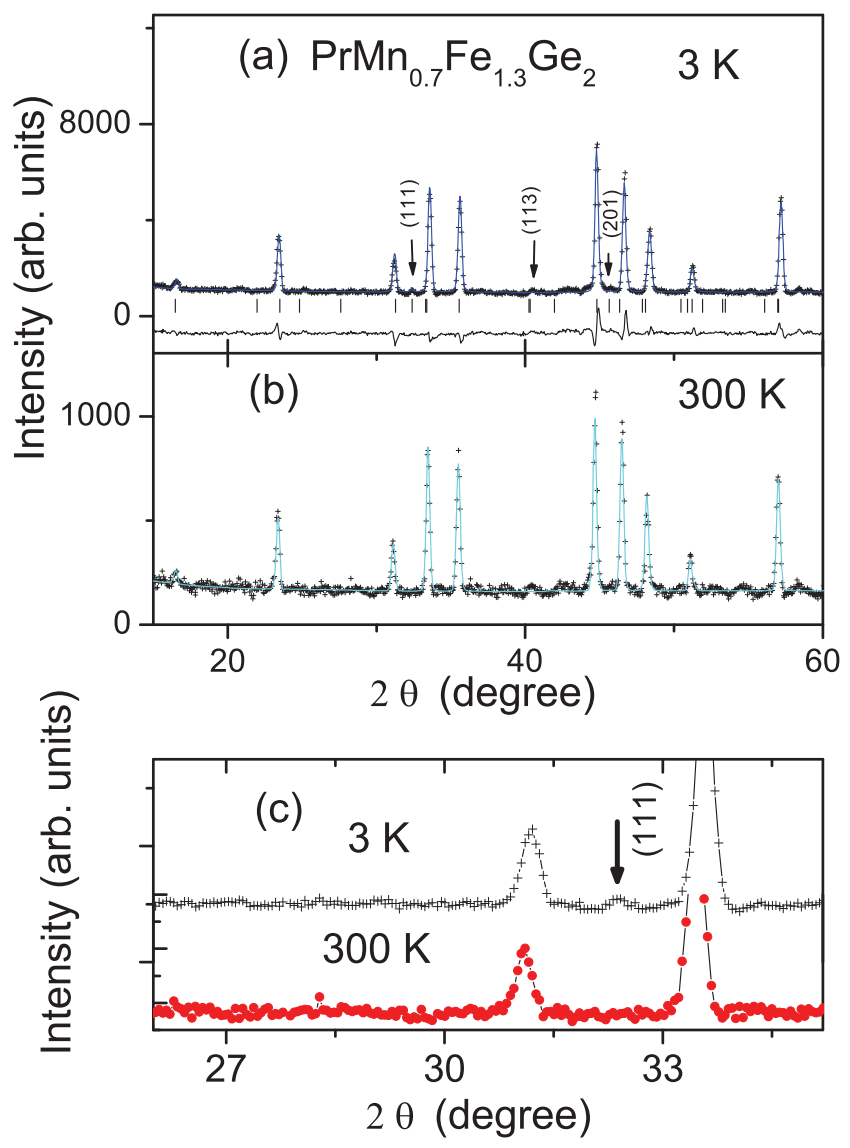


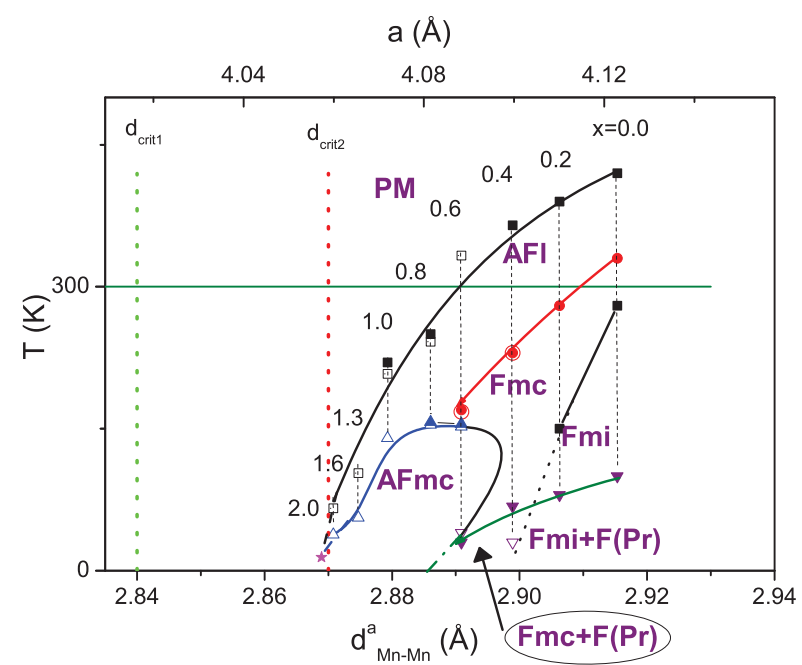


